\title{
DISABLED SPORTS - STEPS TOWARDS A REDUCED EXCLUSION AND A NEW VALUE PARADIGM OF THE SERBIAN SOCIETY
}

\author{
DEPORTE DE LAS PERSONAS CON DISCAPACIDADES - PASOS HACIA \\ LA DISMINUCIÓN DE LA EXCLUSIÓN Y EL NUEVO PARADIGMA DE \\ VALOR DE LA SOCIEDAD SERBIA
}

\author{
Goran Kasum \\ Faculty of Sport and Physical Education, University of Belgrade, Serbia
}

\begin{abstract}
Over the last decade, the sport for persons with disabilities (Disabled Sports DS) in Serbia has been experiencing its development, which is reflected not only by achieving significant sports results on an international scale, but primarily by creating a favorable environment for a greater inclusion of persons with disabilities in sports activities. The ongoing changes also occur as the organizational re-composition of the Paralympic sports system, which is today characterized by a more precisely regulated system, organizational and technological relations established between all the actors involved in the movement itself and the society, as well as more efficient functioning of sports clubs and associations. The fact that the central government has undertaken to fund the achievements of top sports results is especially important for the enhancement and further development of sport of persons with disabilities. On the other hand, the conditions for mass and recreational sports participation should be provided to disabled persons by the units of local self-government. The recovery and rehabilitation of the sports in Serbia, including the sport of persons with disabilities, have coincided with the adoption of the Constitution (2006), the adoption of the Law on Sports (2009 and 2016), as well as the realization of two cycles of the National Strategy for Sports Development (2009-2013 and 2014- 2018). The decision to prepare the Sports Development Strategy for a period of 4 years has allowed for the changes which are not too invasive, ensuring a consensus of all the actors relevant for its implementation, as well as a continuous supervision of its effects including the corrective measures for remedying everything that has been determined as a problem during the implementation and practical application thereof. Based on monitoring the indicators of the Strategy implementation, it can be stated that it has been effectively implemented in the area of adaptive, i.e. disabled sports, and most of the activities envisaged by the action plan have been successfully implemented.
\end{abstract}

Key words: DISABLED SPORTS / NATIONAL STRATEGY / VALUES / SOCIAL DEVELOPMENT / SERBIA

\begin{abstract}
EXTRACTO
Durante las últimas décadas, el deporte de las personas con discapacidades (DPD) en Serbia vive su desarrollo que se refleja no solo en alcanzar importantes resultados deportivos en el escenario internacional, sino también, y ante todo, a través de la creación de un ambiente favorable para la incorporación de las personas con discapacidades en las actividades deportivas. Los cambios que permanecen se desarrollan también como la precomposición organizativa del sistema del deporte paraolímpico, el cual hoy en día refleja un sistema regulado con mayor precisión, una vinculación organizativa y tecnológica de todos los factores del mismo movimiento y la sociedad, como también un funcionamiento más eficiente de los clubes y asociaciones deportivas. Para la promoción y desarrollo del deporte de las personas con discapacidad es de especial importancia lo que el Estado central se encargó del financiamiento de alcance de los mejores resultados. De otro lado, las unidades de autonomía local tienen que asegurar las condiciones para que las personas con discapacidades hagan deportes masiva y recreativamente. La recuperación y saneamiento del deporte en Serbia y con eso del deporte de las personas con discapacidades coincide con la aprobación de la Constitución (2006), aprobación de la ley del deporte (2009 y 2016), como también con la realización de dos ciclos de estrategia nacional de desarrollo del deporte (2009-2013 y 2014-2018). La decisión de hacer la estrategia de desarrollo del deporte para el período de 4 años, creó las posibilidades que los cambios no sean demasiado invasivos, que se asegure el consenso de todos los factores importantes para su realización, como también, que se sigan continuamente sus efectos con las medidas para la corrección de todo aquello que en la aplicación real se enfrentaba con los problemas. Sobre la base de seguir los indicadores de la realización de la Estrategia, es posible constatar que ella en el espacio del deporte de las personas con discapacidades se realiza eficientemente, y que la mayoría de las actividades previstas por el plan de acciones se realizó con éxito.
\end{abstract}

Palabras claves: DEPORTE DE LAS PERSONAS CON DISCAPACIDADES/ ESTRATEGIA NACIONAL/ VALORES / DESARROLLO SOCIAL / SERBIA 


\section{PARALYMPIC SPORTS IN PROMOTING THE RIGHTS OF PERSONS WITH DISABILITIES}

The Paralympic Movement emerged as a sporting competition held in Stoke Mandeville, England in 1950s which involved the World War II veterans with spine injuries. Following these inceptive competitions, persons with disabilities attracted a growing international attention, thus the First Official Olympic Games for disabled athletes were organized in Rome in 1960. Engagement in sports enables people with disabilities to improve their physical, social, affective and functional health, making their recovery and rehabilitation more effective, enhancing the quality of their life, etc. Therefore, participation in recreational or competitive sports is highly and 'strongly' recommended as a kind of therapy, but also as a lifestyle.

Participation in sports facilitates the humanization of social relations for a significant number of citizens, enabling great savings in the social budget, since instead of staying in their family, hospitals or sanatoria, the people with disabilities engaged in sports become more independent, and often start their own family, and as elite athletes they also become famous and publicly popular. Bearing in mind that one of the priorities in working with persons with disabilities is a permanent support to strengthen their spirit, successfully include such persons in the society and make them believe that they can achieve a lot in life, the life stories and achievements of disabled athletes then represent perfect examples of ethical and moral values of a society, being the guidelines for all its citizens how to deal with challenges and difficulties in life.

The great achievements of Paralympians encourage spreading of the sporting spirit and, primarily, lead to a reduced stigmatization in the society, stimulating the development of the Paralympic movement at the national level, with a generally accepted statement that not everyone needs to be a high-level athlete, but everyone will highly benefit from being engaged in sports. In a real academic debate on the issues of national disabled sports as the subject of this paper it should be pointed out that many changes have occurred in the value and system re-composition of the Paralympic movement and overall disabled sports in Serbia since 2006. These changes have been initiated by the DS itself, but also by the political bodies of the central state and the sports system itself. They have been in line with the agenda adopted both within international sports forums and at the level of political decisions by the European Union (EU), Council of Europe (CoE) or the United Nations (UN) agencies. Political documents and resolutions on sports and social inclusion of all citizens including the outcomes related to the field of DS were adopted (2011) at the EU level and the funds have been established to support the social inclusion process. The European Union tends to strengthen the non-discriminatory aspects of the European laws and rules, therefore the principles and the action plan of the European Strategy for Persons with Disabilities (2010-2020) and the Strategy for Equality (2010-2015) were adopted. The entire process has been based on the eight principles contained in the Convention on the Rights of Persons with Disabilities (UN General Assembly, 13.12.2006), which was signed by Serbia on July 31, 2009. According to this Convention, persons with disabilities mean persons who have long-term physical, mental, intellectual or sensory disabilities, which in interaction with different barriers may interfere with their full and effective participation in society on an equal footing with others. The principles underlying the UN Convention are the following:

- respect for inherent dignity, individual autonomy including the freedom to make one's own choices and independence of persons,

- non-discrimination,

- full and effective participation and inclusion in society,

- respect for difference and acceptance of persons with disabilities as part of human diversity and humanity,

- equality of opportunity,

- accessibility,

- equality between men and women, and

- respect for the evolving capacities of children with disabilities and respect for the right of children with disabilities to preserve their identities.

The disabled sports are manifested in a form of the Paralympic Games that are based on a tradition of fair and honorable sporting competitions. The Paralympic movement values are more important than in any other type of sports and they are as follows:

courage that encompasses the unique spirit of the Paralympic athlete who seeks to accomplish what the general public deems unexpected, but what the athlete knows as a truth; 
determination as the manifestation of the idea that Paralympic push their physical ability to the absolute limit;

as an exposition of the idea of athletes shifting their abilities to the absolute limit;inspiration when intense and personal affecton is begotten from the stories and accomplishments of Paralympic athletes, and the effect is applying this spirit to one's personal life;

equality includes the Paralympic sport as an agent for change to break down social barriers of discrimination for persons with disabilities.

In the same period in Serbia, the analysis of sports and political documents and UN, CoE, and EU resolutions in the field of the Paralympic movement has been carried out, and the (re)organization of the DS system has also been launched by establishing its organizational and technological relations, which should lead to the lasting values and legacies for the overall development of the Serbian societies, i.e. an increased inclusion through the scope and more efficient functioning of clubs and sports associations of persons with disabilities.

\section{PARALYMPIC MOVEMENT - VALUE REFORM OF THE SERBIAN SOCIETY}

The first Paralympic Games, under the official name of «9th Annual International Stoke Mandeville Games», were held in Rome in 1960. The athletes from the former SFRY participated for the first time in 1972 and they recorded notable accomplishments until the breakup of this state union. After the breakup of the SFRY, there was a crisis of sporting results in the Serbian sport in general, including the sport of persons with disabilities as well. Poor financial situation, international sanctions in sport (1992-1995), poor organization and, above all, a lack of true values and driving motives, led to the fact that a departure for a competition itself meant a great success to our athletes with disabilities. Their participation in World or European Championships would often be cancelled just a couple of days before their departure, thus it was considered to be a significant improvement if they would manage to arrive to the competition at all. Certianly, in such circumstances, success was rarely achieved, and the medals won actually represented an exceptional endeavour by an indi- vidual and not the result of a serious and organized work. Over the last ten years, the Paralympic sport in Serbia has experienced a significant expansion and has recorded some excellent achievements. The general public is mostly familiar with that 9 medals ( 3 gold, 2 silver and 4 bronze medals) were won at the Paralympic Games in Rome in 2016, that 5 medals (2 gold and 3 silver) were won in London in 2012, while many other great achievements made by our disabled athletes in large competitions have not been promoted and advertised by the media to a greater extent. During the last 12 years, there were 153 medals won only in Para sports and events (Table 2), while additional 217 medals have been won in non-Paralympic sports and disciplines (Table 1). Our Paralympians have been accomplishing a high medal count at World and European Championships year by year, and they have been especially successful in table tennis (Tournaments, 2012-2016), shooting sport and athletics (Publications, 2017), as well as in taekwondo over the past few years (Results, 2013). The sporting success of Serbian disabled athletes, achieved from 2009 to 2012, has significantly contributed to the affirmation of the Paralympic movement and to a better position of the Paralympic sports in the society (Mićović, 2014), so it is not surprising that the medal count achieved only in the Paralympic sports events and disciplines became a three-digit number over the last 6 years. The total number of the medals won in the Paralympic events in the period 2007-2012 is 53, which includes 22 medals won at the Paralympics and World Championships, and 31 won at the European Championships, while in the period from 2012 to 2018,100 medals were won, including 29 medals won at the Paralympics and World Championships, and 71 won at the European Championships (Table 2 ). A similar trend can be observed in non-Paralympic sports and events. From 2007 to 2012, 60 medals were won, including 37 and 23 medals won at the World and European Championships respectively, and in the period from 2012 to 2018, even 157 medals were won, i.e. 75 in the World and 82 in the European Championships (Table 1). The expansion of these sporting achievements in the last decade, with the obvious trend of a steady increase in the number of medals won, requires the factors that enabled the recovery of the disabled sports to be analyzed in order to identify the problems in the organizational efficiency of the system itself, with the aim of affirmation of sports in the function of «healing» the society - its destigmatization. 
Table 1. Medals in non-Paralympic sports and events won in the period 2007-2018

\begin{tabular}{|c|c|c|c|c|c|c|c|c|}
\hline \multirow{3}{*}{$\begin{array}{c}\text { COMPETITION } \\
\text { Year }\end{array}$} & \multicolumn{4}{|c|}{ WORLD CHAMPIONSHIPS } & \multicolumn{3}{|c|}{ EUROPEAN CHAMPIONSHIPS } & \multirow{3}{*}{ TOTAL } \\
\hline & \multicolumn{3}{|c|}{ Rankings } & \multicolumn{3}{|c|}{ Rankings } & \multirow[b]{2}{*}{ III } & \\
\hline & $\begin{array}{c}\text { Disability and Sports } \\
\text { Event }\end{array}$ & I & II & III & $\mathbf{I}$ & II & & \\
\hline 2007 & Deaf & & & & 1 & & 2 & 3 - Wrestling \\
\hline \multirow{4}{*}{2008} & Deaf & & & $\begin{array}{l}\text { 2- Chess, } \\
\text { Wrestling }\end{array}$ & 1-Handball & & & 3 \\
\hline & Special Olympics & & & & $\begin{array}{l}\text { 2-Football } \\
\text { Basketball }\end{array}$ & & & 2 \\
\hline & $\begin{array}{l}\text { Blind and Visually } \\
\text { Impaired }\end{array}$ & & & & & 1 & 1 & 2-Bowling \\
\hline & Bodybuilding & 1 & & & 1 & & & 2 \\
\hline \multirow{3}{*}{2009} & Deaf & & 1- Handball & $\begin{array}{l}\text { 1-Shooting } \\
\text { Sport }\end{array}$ & & & & $2 \mathrm{OG}$ \\
\hline & Special Olympics & 8 & 7 & 3 & & & & $\begin{array}{l}18 \text { Winter } \\
\text { Olympics }\end{array}$ \\
\hline & World Dwarf Games & 1 & 1 & & & & & 2- Swimming \\
\hline \multirow{3}{*}{2010} & Special Olympics & & & & 4 & 2 & 4 & 10 \\
\hline & Deaf & & 1 - chess & & & & & $\begin{array}{l}\text { 1- Chess } \\
\text { Olympiad }\end{array}$ \\
\hline & Shooting Sport & & & 1 & & & & 1 \\
\hline \multirow{5}{*}{2011} & $\begin{array}{l}\text { IBSA*Blind and } \\
\text { Visually Impaired }\end{array}$ & 1 & 1 & & & & & 2- Athletics \\
\hline & $\begin{array}{l}\text { IWAS* International } \\
\text { Wheelchair and } \\
\text { Amputee Sports }\end{array}$ & 1 & 1 & & & & & 2- Athletics \\
\hline & Triathlon & & & & 1 & & & 1 \\
\hline & $\begin{array}{l}\text { Blind and Visually } \\
\text { Impaired }\end{array}$ & 1 & & 1 & & & & 2- Bowling \\
\hline & $\begin{array}{l}\text { Blind and Visually } \\
\text { Impaired. juniors }\end{array}$ & 1 & & 1 & & & & 2-Chess \\
\hline \multirow{3}{*}{2012} & Deaf & 1 Chess & & & & & $\begin{array}{c}1- \\
\text { Handball }\end{array}$ & 2 \\
\hline & Triathlon & & 1 & & & 1 & & 2 \\
\hline & Special Olympics & & & & & 1 -Football & & 1 \\
\hline \multicolumn{2}{|c|}{ Total (2007-2012) } & 15 & 13 & 9 & 10 & 5 & 8 & 60 \\
\hline \multirow{6}{*}{2013} & Deaf & & 1- Handball & 1-Shooting & & & & 2 Deaflympics \\
\hline & $\begin{array}{l}\text { Blind and Visually } \\
\text { Impaired }\end{array}$ & & & & 1 & 1 & 3 & 5- Bowling \\
\hline & Shooting Sport & & & & 1 & 2 & 3 & 6 \\
\hline & $\begin{array}{l}\text { Blind and Visually } \\
\text { Impaired.juniors }\end{array}$ & & 1 & 1 & & & & 2-Chess \\
\hline & Special Olympics & $\begin{array}{c}\text { 6- } \\
\text { Winter } \\
\text { Olympics }\end{array}$ & $\begin{array}{c}5 \\
\text { Winter } \\
\text { Olympics }\end{array}$ & $\begin{array}{c}6 \\
\text { Winter } \\
\text { Olympics }\end{array}$ & $\begin{array}{l}\text { 2- Football, } \\
\text { Basketball }\end{array}$ & $\begin{array}{c}1 \\
\text {-Volleyball }\end{array}$ & & 20 \\
\hline & World Dwarf Games & & 2 & & & & & 2 -Swimming \\
\hline
\end{tabular}




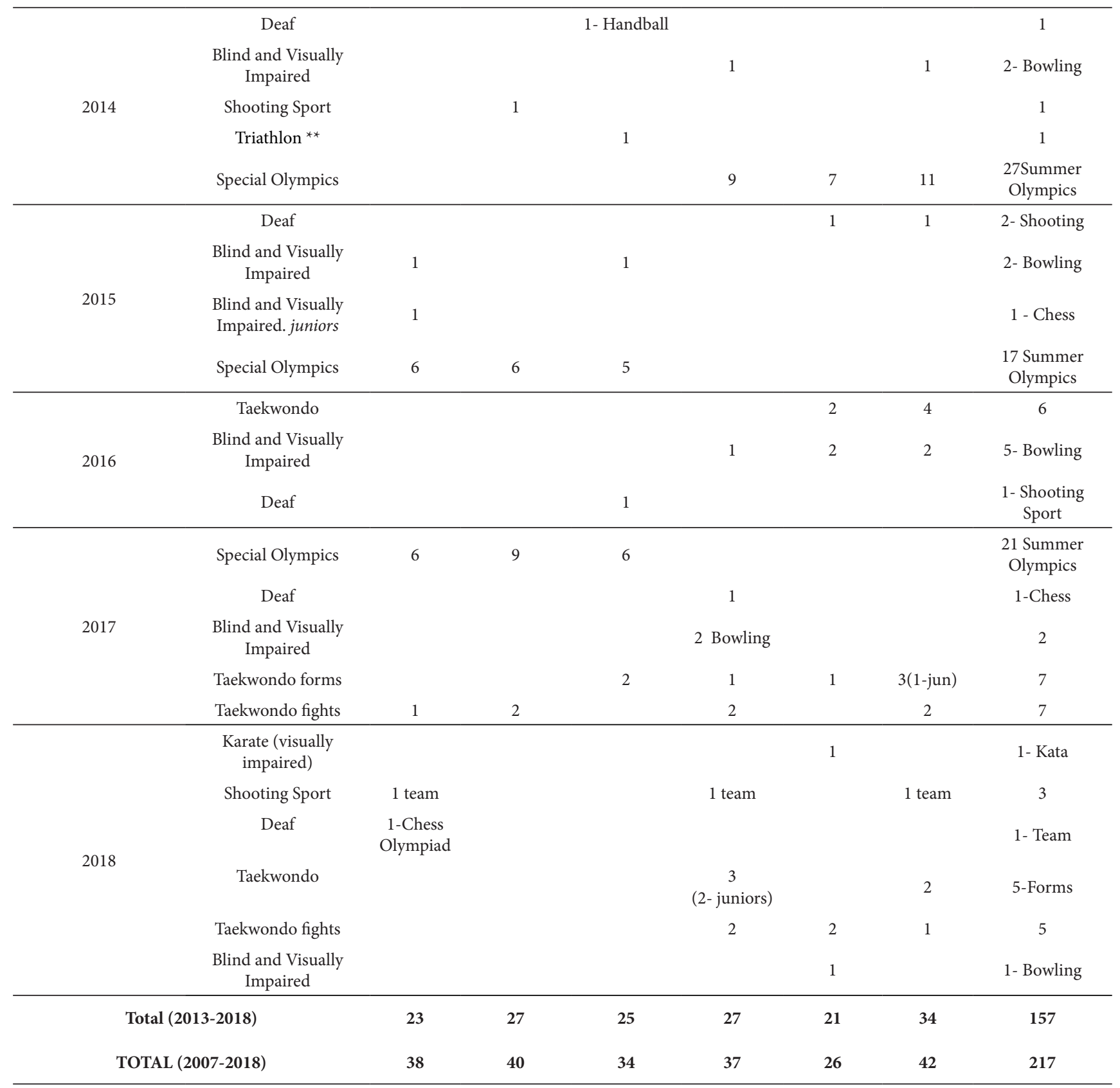

* Pursuant to the Decree on National Awards and Recognitions for Special Contribution to the Development and Affirmation of Sports, which was adopted on April $2^{\text {nd }}$ and with effect from December 2009 (Official Gazette of the Republic of Serbia No. 24/09 and 88/09, 2009), it has been specified that the competitions organized by IPC Athletics ( World Para Athletics, since 2017), a subcommittee of the International Paralympic Committee in charge of athletics, shall be solely considered the World and European Championships in Paralympic Athletics. Thus, since 2010, the European and World Championships organized by the International Blind Sports Federation (IBSA) and the International Wheelchair and Amputee Sports Federation (IWAS), have practically become non-Paralympic events.

** Triathlon was included in the Paralympic programme for the first time in 2016, however, the event in which Lazar Filipović won his medal at the World Championship was not a part of the men's programme but of the women's only, therefore, in this review paper, this achievement has been included in the non-Paralympic events. 
Table 2. Medals in Paralympic sports events and disciplines won in the period 2007-2018.

\begin{tabular}{|c|c|c|c|c|c|c|c|c|}
\hline \multicolumn{2}{|c|}{ COMPETITION } & \multicolumn{3}{|c|}{ WORLD CHAMPIONSHIPS } & \multicolumn{3}{|c|}{ EUROPEAN CHAMPIONSHIPS } & \multirow{3}{*}{ TOTAL } \\
\hline & & \multicolumn{3}{|l|}{ Rankings } & \multicolumn{3}{|c|}{ Rankings } & \\
\hline Year & Sport category & $\mathrm{I}$ & II & III & $\mathrm{I}$ & II & III & \\
\hline \multirow[b]{2}{*}{2007} & Table tennis & & & & 1 & 1 & 1 & 3 \\
\hline & $\begin{array}{l}\text { IBSA }^{* * *} \text { Blind and } \\
\text { Visually Impaired }\end{array}$ & & & 2 & & & & 2 - Athletics \\
\hline 2008 & $\begin{array}{l}\text { Paralympics Athletics, } \\
\text { table tennis }\end{array}$ & & 2 & & & & & 2 \\
\hline 2009 & IWAS $^{* * *}$ Wheelchair & 1 & 2 & 1 & & & & 4-Athletics \\
\hline \multirow{4}{*}{2010} & Table tennis & & & & 2 & 1 & 2 & 5 \\
\hline & Athletics & & & & 3 & 4 & 3 & 11 \\
\hline & Table tennis & & 1 & 2 & & & & 2 \\
\hline & Shooting sport & 1 & & & & & & 1 \\
\hline \multirow{2}{*}{2011} & Athletics & 1 & 3 & 1 & & & & 5 \\
\hline & Table tennis & & & & 3 & 1 & 1 & 5 \\
\hline \multirow[b]{2}{*}{2012} & Athletics & & & & 5 & 1 & 2 & 8 \\
\hline & Paralympics & 2 - Athletics & $\begin{array}{l}3 \text { (athletics - } 1 \text {, } \\
\text { table tennis- } \\
\text { 2) }\end{array}$ & & & & & 5 \\
\hline \multicolumn{2}{|c|}{ Total (2007-2012) } & 5 & 11 & 6 & 14 & 8 & 9 & 53 \\
\hline \multirow{3}{*}{2013} & Table tennis & & & & 1 & 1 & 2 & 4 \\
\hline & Shooting sport & & & & 2 & 1 & 2 & 5 \\
\hline & Athletics & & 1 & & & & & 1 \\
\hline \multirow{3}{*}{2014} & Shooting sport & & 1 & & & & & 1 \\
\hline & Athletics & & & & & 5 & 1 & 6 \\
\hline & Table tennis & 1 & & 3 & & & & 4 \\
\hline \multirow{3}{*}{2015} & Athletics & 1 & 2 & 2 & 1 & 2 & 1 & 9 \\
\hline & Table tennis & & & & 1 & 2 & 1 & 4 \\
\hline & Powerlifting & & & & & 1 & & 1 \\
\hline \multirow[b]{3}{*}{2016} & Triathlon & & & & 1 & 2 & 1 & 4 \\
\hline & Athletics & & & & 2 & 2 & 2 & 6 \\
\hline & Paralympics & $\begin{array}{c}3 \text { (Athletics, } \\
\text { shooting, table } \\
\text { tennis) }\end{array}$ & $\begin{array}{l}\text { 2(Athletics } \\
\text { table tennis) }\end{array}$ & $\begin{array}{r}\text { 4(Athletics- } \\
\text { spor } \\
\text { Table te }\end{array}$ & $\begin{array}{l}\text { looting } \\
-2) \\
\end{array}$ & & & 9 \\
\hline \multirow{3}{*}{2017} & Table tennis & 1 - team W & & 1- team M & 2 & & 4 & 8 \\
\hline & Athletics & 2 & & 1 & 2 & & 4 & 9 \\
\hline & Taekwondo & & & 2 & & 1 & 2 & 5 \\
\hline \multirow{5}{*}{2018} & Athletics ${ }^{* * * * *}$ & & & & 3 & 2 & 8 & 13 \\
\hline & Table tennis & 1 & & & & & & 1 \\
\hline & Shooting sport & 1 & & & 1 & 1 & & 3 \\
\hline & Taekwondo & & & & & 3 & 3 & 6 \\
\hline & Badminton & & & & & & 1 & 1 \\
\hline \multicolumn{2}{|c|}{ Total (2013-2018) } & 10 & 6 & 13 & 16 & 23 & 32 & 100 \\
\hline \multicolumn{2}{|c|}{ Total (2007-2018 } & 15 & 17 & 19 & 30 & 31 & 41 & 153 \\
\hline
\end{tabular}

*** The first version of the Decree on National Awards and Recognitions for Special Contribution to the Development and Affirmation of Sports from June 2006 (Official Gazette of the Republic of Serbia No. 65/06, 2006) concerned only the Olympics and Paralympics, and in January 2007, it was extended to refer to the World and European Championships in Olympic and Paralympic Sports (Official Gazette of the Republic of Serbia No. 6/07, 2007). This Decree did not specify the competitions and events it referred to, so that all the World and 
European championships in athletics, organized by the International Paralympic Committee Athletics (IPC Athletics), the International Blind Sports Federation (IBSA) and the International Wheelchair and Amputee Sports Federation (IWAS), as well as any competitive events and discplines, were considered the Paralympic sports.

**** Taekwondo, as a Paralympic sport, first appeared at the Paralympics held in Tokyo, and the only Paralympic event included the fights of competitors with an upper-limb impairment (K40), and only in + K43 classes (K43 and K44). Therefore, the results achieved in the Forms event, as well as the Fights in the K41 and $\mathrm{K} 42$ classes, have been classified into non-Paralympic events.

***** In athletics, two or more classes are often merged, therefore, all the medals won at the World and European Championships organized by the IPC Athletics have been listed herein, regardless of whether a competition class was included in the programme of the next Paralympics or not. For instance, out of 13 medals won at the European Championship in 2018, 10 medals were won in the classes which will feature in the Tokyio Paralympics program, however, the remaining 3 medals were also won in the classes included in the Paralympics program in the last decade, so that it would not be a surprise if some of these three classes were included in the official program of the Paralympics in Paris. Furthermore, if a class is merged with an upper class, this means that it will be more difficult for the athletes to win a medal, since they will compete against the athletes with a lower level of impairment, i.e. the athletes with a less severe disability.

\section{COMPETITION OUTCOMES OF DISABLED ATHLETES AND A PROCES OF THE SERBIAN SOCIETY DESTIGMATIZATION}

Many authors who deal with the issue of sports and physical activity of persons with disabilities have pointed out its great significance for this population (Dausen, 1977; Drench, 1994; Valliant, Bezzubyk, \& Daley, 1990; Winnick,1995). Adverse consequences that accompany a long-term inactivity as well as positive effects that physical activity has on the psychological and physical condition of a body have been explained in detail in the literature (Kasum, 2007; Bacanac et al., 2014). Sport and physical exercise represent a favourable ground for the development of a positive self-perception in life and persons with disabilities become more resourceful in different life situations by years (Kasum and Mladenovic, 2017). Despite these unambigous statements which have been also scientifically verified as positive, a relatively small number of persons with disabilities were involved in sports activities in Serbia until several years ago. In 2009, there were about 17,000 athletes with disabilities registered in the Serbian Association of Sports and Recreation of the Disabled, which only represented slightly more than $2 \%$ of the total number of disabled persons in Serbia. Furthermore, this number has been considered to be unrealistic since many registered athletes were not truly engaged in sports activities, but they were just «an administrative fact» (Kasum and Mijić, 2009). A percentage of persons with disabilities involved in sports activities varies in relation to the region and local community where they live and work out, and it is important to note that this number significantly varies according to a type of disability. Hence, $12 \%$ of the population with mental retardation and only $3 \%$ of people with physical disabilities were engaged in sports activities in Novi Sad (RSAP Vojvodina, Provincial Secretariat for Sports and Youth, 2008).

One of the main reasons underlying such a participation, which cannot definitely be considered as high, is an insufficient awareness of the necessity of sports activities, both for persons with disabilities and their family members. For this exact reason, raising the public awareness of the importance and role of DS has been emphasized as one of the greatest priorities in the development of disabled sports. This represents a long-term task, which requires constant and systematic work and effort.

The legal regulations related to the field of DS have been modified and amended quite easy and quickly, so it has turned out to be far easier to remove a possible legal obstacle to mass participation in sports activities of the disabled than to change the attitudes to and the viewpoints on this issue. Generally, it may be concluded that positive attitudes of the social environment are one of the key prerequisites for a greater inclusion of persons with disabilities in sports activities (Orlić et al., 2016). By raising public awareness, the number of sports clubs for ablebodied athletes where athletes with disabilities are enabled to practise sports is also gradually increasing. This process is two-fold, therefore, a greater readiness of the social environment to accept and support the disabled to become engaged in sports makes their involvement in sports activities much easier, whereas, on the other hand, their mass participation makes it easier for the social environment to become accustomed to and approve this process, offering their unwavering support.

In practice, it may be also observed that some local self-government units (LSGU) have taken a more agile approach to this problem. Thus, a club that wants to withdraw certain funds based on the results achieved by a disabled athlete must be registered for 
the DS sports, and the funding priority is given to the programs that encourage these activities. Many coaches and sports professionals have discovered their professional orientation and become recognized experts in their field exactly due to their commitment to preparing and coaching athletes with disabilities. There is an increasing number of clubs where toplevel athletes with disabilities have found their place in teams composed of able-bodied sport competitors, which certainly represents a great benefit to this work method. There are examples of people with disabilities becoming the first-team members of local sport clubs and even national team members sometimes. The achievements accomplished by disabled athletes result in a considerable personal benefit, but it is also beneficial to their families, coaches and sports professionals, work organizations, other people with disabilities as well as the entire community, either directly or indirectly. In a word, the Serbian society has advanced in medicine and surgery, i.e. surgical operations, which can eliminate or reduce a degree of biomedical impairment, but it has also created opportunities for an integrated rehabilitation through sports. The attempts to introduce adaptive sports (e.g. wheelchair sports), but also to carry out the modification and humanization of architectural barriers in the surrounding environment may be observed. Serbia is gradually, although maybe not at such a high rate as the EU countries do, undergoing a process of destigmatization of its society, striving to be a good place to live for all its citizens!

Numerous positive effects and benefits that persons with disabilities gain through participation in sports have contributed to the fact that most of those who have become engaged in sports activities maintain this habit for many years. It is not uncommon for individuals to start practicing multiple sports, often competing in several sports events and, sometimes, even in completely different sports disciplines. However, the very beginning of their engagement in sports, which is most often associated with an accidental encounter with a coach or other disabled athletes, is still the biggest concern. The stories about such encounters usually sound quite interesting, but they also indicate the problem of scepticism, lack of information and organization of persons with some type of impairment. This could be determined as a personal factor that limits their social inclusion! In fact, the personal factor exactly seems to be the biggest obstacle to include persons with disabilities in sports, since the analysis of everything done in the previous period has shown that good sports conditions for their further sports training have been provided. Briefly, the time has come for a more comprehensive and more humane social understanding of the issue of disability.

One of the reasons for these individuals not participating in sports can be also found in a poor connection between the process of physical education teaching, both in regular and specialized schools, as well as in their inclusion in training and competitive activities, both in the field of regular sports and in the area of alternative and innovative sports for persons with disabilities. Therefore, their inclusion in school and university sports, as one of the important courses of these individuals' development through sports, must be carried out, where significant results in terms of both quantity and quality of disabled sports may be achieved with relatively small investments. Children and young people with disabilities timely involved in the realization of such programs would show a greater sense of safety, self-esteem and emotional control, developing their abilities, communication, sensitivity to others' needs and better socialization more successfully (Howe, 2011). Their parents would be provided an opportunity to discover their children's potentials and abilities, develop the skills to support their improvement and provide encouragement, but also to develop realistic attitudes towards the current abilities of their children and their future. It may be useful to mention that participation itself is a primary goal of disabled sports, but the importance of sports that would make their disability less restrictive must not be neglected. Children who belong to the regular population accept diversity as something natural and develop empathy for the needs of children with disabilities. Such organized sports activities would be also beneficial to the parents of able-bodied children, school teachers, coaches, as well as those who are involved, either directly or indirectly, in these processes. Such approaches and inclusive sports programs are especially useful and important for children with a motor impairment (Kasum, \& Mijić, 2009).

The life stories of our numerous elite Paralympians, but also of some of the world's top-level athletes with disabilities, represent a kind of apotheosis of inclusion, propagating this idea in the best way possible. Management of the successful athletes' biographies includes the measures that should lead 
to a reduced exclusion and promote inclusion at the same time. Although the idea of inclusion and its importance is becoming more understood and accepted, there is a lot of space remaining for its promotion and improvement. A more direct and more specific relationship between the realization of physical education teaching and inclusion in sports clubs represents a logical step in improving this valuable and advanced idea. Truth to tell, inclusion must not and cannot be regarded as a specific issue and problem of sports. However, it stems from a social situation around which all societies, including the Serbian one, have to conduct and foster open and constructive dialogues.

The great achievements made by our Paralympic athletes on the international scene also indicate the society's concern for the population with disabilities, and a level of concern for the disabled is one of the most prominent indicators of a society's level of development. In modern societies, attitudes towards and concern for minority groups, including persons with disabilities, are considered an indicator of the society's development. The sporting success achieved by the Serbian Paralympians over the past decade has largely contributed to the promotion of our society, sending a nice and positive picture of the Serbian society to the world. Investments in disabled sports are of great importance to this population, representing significant investments in the development and quality of the entire society at the same time. The experiences of other developed countries, which have realized these facts earlier than Serbia, have shown that, when it comes to sports activities, adaptive or disabled sports represent the most successful, the most attractive and the least expensive method of a permanent psychological and physical rehabilitation of persons with disabilities. For all the above reasons, investments in DS represent an obligation of the society, as well as a great opportunity for the society to provide something beneficial and valuable, both for the population of persons with disabilities and the society as a whole.

\section{PARAOLYMPIC MOVEMENT AND IMPROVEMENT OF THE SPORTS SYSTEM IN THE REPUBLIC OF SERBIA}

An increasing interest in understanding the factors which lead to exclusions, as well as to the effective management aimed at the reduction thereof, has been observed in sports, which is, to a certain extent, also indicated by the sports strategies adopted in Serbia. The Action Plan, arising out of strategic documents, considers DS and provides the frameworks for reducing exclusions, but also develops a value innovation approach by which sport becomes an instrument in the fight against all forms of segregation in the society.

The sports system includes any natural and legal persons engaged in sports activity as the participants in the sports system (Đurđević, 2015). The sports system is a relevant sports entity within a state that leads to a progress in its fields, such as sports, physical education and sports for all. Both practical and theoretical knowledge suggests that any changes in the parts of the sports system or its whole, relationships and relations, organizational culture, etc. can be realized only by the consensus among all actors and in the belief that the process of change will be beneficial to the future status of sports, athletes and coaches (Jevtić, 2011).

A crisis in sporting achievements, which have been one of the best methods of integrating various actors of any society ever since, made many minds to deal with this issue, hence, the Framework of the new sports system was adopted in a joint session attended by all Serbian sports actors, which was held in July 2006, when a step forward was made in creating an environment for a further development of sports in the state-independent Republic of Serbia, and on September 30, 2006, the RS Constitution, in which sport has also found its place, was adopted (Jevtić, 2011). In an attempt to fully consider sport as a powerful instrument for the development of a comprehensive society, primarily at the initiative of national sports organizations and by lobbying in the Serbian political system, the Ministry of Youth and Sports was established under the Law on Government and Ministries from 2007. Prior to the political reorganization in favor of sports, the Decision on national awards and recognitions for sports achievements was adopted. The first awards were solemnly awarded on February 15, 2007, whereby the Olympic and Pararlympic sport in Serbia were treated equally. All of this represented a great start of the equal and unique treatment and the sports system regulation in the state-independent Republic of Serbia. By adopting the RS Sports Development Strategy(DS), on December 2, 2008, the process of regulating and organizing the sport itself and its surroundings was continued. 
The fact that the state has undertaken to fund elite sports is of special importance for the improvement and development of the DS in Serbia. The preparation of paralympic athletes for large competitions, as well as their participation in these events, is very expensive. It would be almost impossible for anyone else except for the state to reimburse the high DS expenses in the long run. In addition to providing the conditions for a better preparation, the scholarships provided to the high-level competitors are also of great importance, as well as national awards and recognitions given to those who achieve top-level sports results (medals in the Paralympics, World and Continental Championships in paralympic sports and events). The path to the top-level sporting success is not easy, regarding both Olympic and Paralympic sports, and it is usually impossible to achieve such a success without the support of the entire society. The great achievements made by our Paralympic athletes in the last 10 years coincided with the period during which the Serbian sports system underwent significant changes. The International Paralympic Committee has established a total of 30 sports out of which 14 categorized Paralympic sports events included in the Paralympic programme function successfully under the auspices of the Serbian Paralympic Committee, as follows: athletics, table tennis, shooting sport, swimming, archery, sitting volleyball, powerlifting, cycling, skiing, goalball, wheelchair basketball, canoe, badminton, taekwondo. As for the non-categorized sports events, the greatest achievements have been accomplished in triathlon and, to a lesser extent, in judo, and competitions and training activities are also organized in boccia and para dance sport, which is a member of the International Paralympic Committee, although not featured in the Paralympic programme.

It can be stated that the elite Paralympic sport has been taken care of, which has made the persons responsible for regulating this field to focus on other levels of disabled sports. Elite sport is an important area, but there is quite a small number of athletes engaged in the top-level sports. Therefore, a solution regarding mass and recreational sports has been found in the local self-government units. According to the Law on Sports from 2016 (Article 137), local self-government units shall provide funding, out of their own budgets, in order to satisfy the citizens' sport-related needs and interests, which is very important especially for the persons with disabilities who want to practise sports primarily for health purposes and personal satisfaction. Under the Law on Sports, this has been exactly recognized as one of the priorities that must be respected when selecting the programs which are to be funded out of the budget of local self-government units in the current year (Article 138, paragraph 7). The priority defined as „Enhancing and creating the conditions for improving recreational sports, i.e. citizens' participation in sports, especially of children, youth, women and persons with disabilities" means that it is required, primarily in this field, to fund certain programs to the extent that ensures adequate satisfaction of the citizens' needs to be personally engaged in sports (especially of children, youth, women and persons with disabilities). Other programs may be approved only once the citizens' needs belonging to the above priorities have been satisfied. In addition, unlike the Ministry of Youth and Sports, which may finance, out of its budget funds, only those programs belonging to the sports disciplines of special importance for the Republic of Serbia, the units of local self-government, pursuant to Article 138, paragraph 8 of the Law on Sports, may also approve, on an annual basis, special programs belonging to all sports disciplines and fields as established by the Rulebook on sports disciplines and fields in the Republic of Serbia as well as sports events included in sports disciplines and fields (Udovičić, 2016). Additionally, under Article 4, paragraph 11 of the Law on Sports, it has been stipulated that the Republic of Serbia, Autonomous Province, local self-government units and sports organizations will undertake special activities to increase the participation of children, youth, women and persons with disabilities in sports activities, enable massification of women's sports organizations and ensure equal treatment to women and persons with disabilities in sports. The construction and equipping of sports facilities which must be accessible to people with disabilities is also considered a priority (Đurđević and Đukić, 2016). When preparing and developing spatial and urban plans, special attention should be paid to the purpose of spaces designated for sports and recreation of children, youth, persons with special needs and citizens. It has been recommended that medium-sized cities should provide functional sports facilities, while the construction of large sports complexes should be carried out by large cities. By the Law on Sports of the Republic of Serbia, it has been defined that all the units of local self-government shall determine the sports development programs in their territories within six months follow- 
ing the adoption of the National Sports Development Strategy of the Republic of Serbia, and in accordance with the National Strategy (Article 142, paragraph 4). Notwithstanding, according to the Sports Development Strategy of the Republic of Serbia 2014-2018 (Art 192, paragraph 5), the time frame was one year, since most of the local self-government units did not have sports development programs in place nor any experience in the strategic planning of sports development, so it was considered that the preparation of this first program would take a little bit longer. In any case, local self-government units have taken a serious approach to solving this problem, and disabled sports have become an integral part of these programs.

Although the local self-government authorities are not primarily responsible for elite and professional sports, it does not mean that these levels of sports are not of major importance for every society, thus, local public authorities also play a role in supporting the development of elite and professional sports. Such support is of great importance, which is, above all, reflected in the reverse effect which elite sports have on motivating a wide range of people to participate in sports, followed by the economic contribution that modern elite sports provide to each community and national promotion (and even promotion of local communities) through achieving top-level sports results, but also due to the need of a specific number of people (athletes) not to be satisfied with an average, but to strive for the maximum sport performance and the highest-level results. For all the above reasons, the elite sports development has been supported by local self-governments, in addition to a direct support of the state (by Ministry of Youth and Sports, Serbian Paralympic Committee and national sports associations).

\section{DISABLED SPORTS IN THE NATIONAL SPORTS DEVELOPMENT STRATEGIES (2009 and 2013)}

Having defined the term of the Sports Development Strategy to be a 4-year period, an opportunity to make the changes that are not too invasive, as well as to ensure the consensus of all the actors relevant for its implementation, has been created. This approach has also facilitated monitoring the effects and remedying everything that has been found problematic in its implementation and practical application. The implementation of the Strategy itself has been elaborated and concretized through the Action Plan (RS Ministry of Youth and Sports, 2009), and the recovery and rehabilitation of sports in Serbia, including the sports for persons with disabilities, have coincided with the adoption of the RS Sports Development Strategy. A part of the Strategy which refers to DS has been given a special attention in this review paper.

The main goals of the RS Sports Development Strategy adopted for the period of 2009-2013 in the field of disabled sports, are as follows (RS Ministry of Youth and Sports, December 2, 2008):

- improving the conditions for a mass participation of persons with disabilities in sports activities, and

- raising public awareness of the importance and role of disabled sports.

- In order to realize the first goal, the following activities have been envisaged:

- defining the criteria for determining the status of elite DS in relation to the status of other types of sports activities which persons with disabilities are engaged in;

- implementation of the elite Paralympic sports development program and realization of the international competition program by the SPC (Serbian Paralympic Committee);

- implementation of the mass recreational sports and elite non-Paralympic disabled sports development program, as well as the national competition program by the SSIS (Serbian Sports Association of Persons with Disabilities);

- implementation of the program of development of sports events: Special Olympics, Sports for Deaf and Hearing-Impaired Persons and Sports for Blind and Visually Impaired.

In addition to the positive effects which it has on the psyche, physical ability and independence of persons with disabilities, sport also represents a factor of social integration and an opportunity for economic and professional satisfaction (Kljajić et al., 2013). It has been accepted that elite DS should be funded by the Serbian Paralympic Committee and mass recreational sports should be financed by the Ministry of Labor, Employment, Veterans' Affairs and Social Affairs, the Agency for Cooperation with the Non - Governmental Sector, as well as by the local self - government units. Thus, programs of top-level athletes with disabilities have been funded separately from programs of sporting events that 
involve persons with disabilities, such as manifestations and events organized on the occasion of International Day of Persons with Disabilities, International Women's Day, Statehood Day, as well as various tournaments, meetings, camps, etc. By equalizing the results achieved by both Olympic and Paralympic athletes, a very transparent classification of athletes on the basis of the achieved results has been enabled, as well as the categorization of individual sports disciplines. Based on the results achieved by disabled athletes, it is possible to nominate deserving athletes, international-level athletes and state-level athletes, and, if necessary, low-level athletes. It can be noted that the Strategy activity of «Defining the criteria for determining the status of elite disabled sports...» has been successfully planned and realized!

Bearing in mind the main idea of the Paralympic Movement, which emphasizes that disability does not represent an obstacle to equal participation in society, sports and achievement of goals (Šiljak, et al., 2010), it is quite clear that a constant improvement in the quality of training conditions provided to athletes with disabilities, training and professional development of the staff, as well as the modernization of equipment and facilities, are not only the basis for achieving top sports results, but also the way to improve the quality of life of this population. Considering the fact that in the three Paralympic cycles preceding the Strategy adoption, a total of five medals were won (two silver medals in Beijing in 2008, two bronze medals in Athens in 2004 and one silver medal in Sydney in 2000), and following the adoption of the Sports Development Strategies for the periods 20092013 and 2014-2018, a total of 14 medals were won (5 in London 5, and 9 in Riga), it can be stated that one of the Strategy priority activities - the development of elite paralympic sport has not been only realized, but also resulted in exceptional Olympic results. By generalizing the above statements, it may be noted that the activity of "Implementation of elite paralypmic sports development program and realization of international competition program achieved through the program activities of the Serbian Paralympic Committee» has been also successfully planned and realized.

In addition to the implementation of elite Paralympic sports development program, the Sports Development Strategy also envisages the implementation of mass and recreational sports development program, as well as the development of sports events such as
Special Olympics, Sports for Deaf and HearingImpaired Persons, Sports for the Blind and Visually Impaired, as well as elite non-Paralympic sports for persons with disabilities. The activities which involve the development of these sports events have been considered a priority according to the Strategy. Our athletes have recorded great achievements on an international scale in these sports events. The National Sports Association of the Blind and Visually Impaired was established on October 29,2009 and, since its establishment, it has been engaged in chess, athletics, swimming, goalball and bowling, and occasionally in other sports as well (National Sports Association of the Blind and Visually Impaired, 2018). The success accomplished by our blind and visually impaired athletes is well-known by both sports and general public. Occasions for rejoicing have been provided so many times by our javeline throwers, Tanja Dragić (double world champion in Christchurch and Antalya in 2011, European champion in 2012, goldmedal winner at the Paralympic Games in London), Nemanja Dimitrijević (bronze medal at the World Championship in 2015, silver medal at the European Championship in 2016, and bronze medals at the Paralympics in Riga and the European Championship in 2018) and Miloš Grlica, who, having won two bronze medals at the Paralympics in Athens and at the World Championship in 2007 and having become a European champion in 2005, «added» a silver and a bronze won at the World Championships in Christchurch and Antalya in 2011, following the Strategy adoption, and also became the Europe championship winner in 2012 and the European vice-chamion in 2014, together with the discus throwers, Stefan Dimitrijević and Duško Sretenović, who won the bronze medals at the European Championship in 2018. The amazing achievements have been made by our blind and visually-impaired bowlers and the medals won in the greatest competitions by our chess players and karatekas (Table 1) have made all of us happy. Additionally, the athletes competing in goalball and judo should also be mentioned, since they have put in some excellent performances on the international scene, although they did not win any medals.

The Special Olympics was established in Serbia in 2002 and it currently includes 12 sports (athletics, swimming, skiing, badminton, boccia, bowling, table tennis, tennis, basketball, volleyball, handball and football). The Special Olympics programme featured 3000 athletes until 2014, and their medals won are 
hard to count. The competitions of mixed teams, composed of able-bodied athletes and persons with intellectual disabilities, are gaining in popularity, in addition to a mass participation. This type of sporting competitions is of great importance to children with developmental disabilities and their parents, as well as to typicaly developing children and their parents. These activities make all of them stronger, better and emotionally wealthier, and the contacts established in this way significantly contribute to finding the right place and role of people with disabilities in a wider social community. In Serbia, there are 11 such clubs already established and operating, and the Special Olympics is open to all initiatives to include new sports events.

The Serbian Sports Association of the Deaf organizes competitions even in 16 sports (athletics, football, handball, basketball, swimming, wrestling, bowling, volleyball, table tennis, shooting sports, darts, karate, judo, taekwondo and chess). From 1945 to 2005, the deaf athletes of the SFRY and the FRY won 75 medals ( 27 gold, 17 silver and 31 bronze medals) at the World and European Championships for the Deaf and the Deaflympics (Sports Association of the Deaf of Serbia, 2015), and from 2007 to the end of 2018, the athletes of this Association won 19 medals at the greatest competitions (Table 1). The objective of this Association is quite clear, i.e. to involve as many athletes as possible in the work of the clubs of «hearing» athletes. Everything done in these sports events leads to the unequivocal conclusion that the strategic goal of «Implementation of the development program of sports events such as Special Olympics, Sports for the Deaf and Hearing-Impaired Persons and Sports for the Blind and Visually Impaired» has been planned and realized very successfully!

The competitions in non-Paralympic sports and events, such as bowling, orienteering, karate, sport fishing, water skiing, chess, darts, billiards, as well as mountaineering and mountain climbing, are largely popular among people with disabilities, and the results achieved in these sports are worthy of attention (Kasum, 2015, p. 157). Furthermore, the number of sports events has not been fixed, so there is always an open possibility to organize competitions in a new sports event, where no competition has been organized so far. By reviewing these undertakings, it can be stated that the activity of «Implementation of mass and recreational sports and elite non-Paralympic sports development program, as well as na- tional competition program by SSIS (Serbian Sports Association of Persons with Disabilities)» has been successfully implemented.

Having considered the aforementioned, it may be concluded that the first goal set in the Strategy and defined as „Improving the conditions for a greater participation of persons with disabilities in sports activities", has been realized to a greater extent. The favourable conditions have been created for persons with disabilities to be engaged in sports and become elite athletes, and their participation is gradually increasing. Of course, this process has not ended yet and it requires a constant work, however, a lot has been done on this issue.

In order to realize the second goal set in the RS Sports Development Strategy for the period 20092013, defined in the field of disabled sports as «Raising public awareness of the importance and role of sports for persons with disabilities,» the activity of «Continuous education of parents, representatives of local self-government units, educational institutions and citizens about the importance of participation of persons with disabilities in sports as well as the fact that disabled persons are equal participants in sports competitions» has been envisaged. These activities are constantly being realized, therefore, a lot has been done in regard to this issue. Certainly, the awareness of people cannot be changed as fast as rulebooks, documents, laws, etc. so it requires strenuous and constant work. Yet, some positive effects can be observed. A growing number of parents are becoming more interested in and they want to know where their disabled children can exercise and practice sports, and they often become actively involved in their children's sports activities. A large number of brochures and attractive promotional materials are intended especially for parents, and in addition to only enrolling their children in organized sports activities, parents are also becoming more involved in the procurement of equipment and preparation of sport polygons, assisting in the activities, and often becoming personally engaged as active participants in sports competitions. When it comes to the professional staff, appropriate solutions are sought out in this field as well. For example, the Sports Association of the Deaf of Serbia has stated that this Association has only 7 operational coaches engaged (two in football, two in handball and three in shooting sport), therefore, since the Association cannot provide professional development, they send their staff to professional trainings 
organized by branch associations of the hearing and, if necessary, they appoint sports professionals from the association of the hearing (2015, page 4). For a dozen of years already, at the faculties of sport there are education courses, either compulsory or elective, which deal with the issues of sports for persons with disabilities and the students may choose this field as their major. In addition, there are education courses for coaches established at the faculties, and upon successful completion of these courses the students will gain the title of an operational coach in the selected sports event (Paralympic sports, non-Paralympic sports for persons with disabilities, Special Olympics, Sports for the blind and visually impaired, Sports for the deaf and hearing-impaired) and there is a growing interest in these courses as well. Over a few years only, a large number of deaf children have been included in schools attended by hearing children through a process of inclusion, so that the number of children enrolled in the elementary and secondary schools for the deaf has been decreased by 6 to $7 \%$ in relation to the period until 2011 (Sports Association of the Deaf of Serbia, 2015, page 8). Hence, these children are more referred to sports clubs of the hearing, and the possibilities of their inclusion and participation in sports activities are much higher. On the other hand, hearing children become almost imperceptibly accustomed to their deaf friends, which results in a significant contribution to raising the general public awareness.

Generally, the envisaged activity of "Continuous education of parents, representatives of local selfgovernment units, educational institutions and citizens about the importance of participation of persons with disabilities in sports as well as about the fact that disabled persons are equal participants in sports competitions» has been quite comprehensively planned and realized. Truth to tell, the indicators of the implementation of most of these activities have become more noticeable over the last 2-3 years, however, this does not imply that it has not been timely implemented, according to the time frame specified in the Strategy (2009-2013). Education is a lasting process, and educational actions are always most difficult to design and initiate. The courses and seminars which are currently top-ranked have emerged as a logical consequence of the work during the past 6-7 years. A favorable environment has been created and the wider public has been aroused. The implementation of this activity requires continuity.
The Sports Development Strategy of the Republic of Serbia for the period 2014-2018 is a logical sequel to the 2009-2013 Strategy, which was particularly focused on providing the youth, elderly and persons with disabilities with special opportunities for practising sports i.e. developing their personalities through the programs tailored to their needs and requirements. It has been already pointed out that the public authorities of all levels have to undertake additional measures in the field of sports in order to enable persons with disabilities, as well as other members of the society, to use the opportunity to participate in sports efficiently, regardless of a given degree of disability. Thus a step forward has been made in the prevention of discrimination and marginalization of the disabled and a scope of this population's participation in sports has been increased. The specified objectives of the Strategy include a greater involvement of the local self-government units in funding the program activities in the field of sports and recreation for persons with disabilities, as well as improving the cooperation between recreational sports and school and university sports, elite sports, military and police sports, workers' sports and sports in the countryside, with the aim of increasing a scope of participation of persons with disabilities in sports (and other segments of the population as well).

According to the Action Plan for the Strategy implementation it has been envisaged that the system of school and university sports should provide social integration of pupils and students with disabilities. These tasks have been realized, so that some promotional competitions were held according to the Unified system, which is based on the competitions of mixed teams, composed of athletes with disabilities and able-bodied ones. These competitions provide a great opportunity for a significant inclusion of pupils and students with disabilities in sports (Kasum, \& Mijić, 2009), although it has not been sufficiently utilized so far. It may be concluded that these strategic goals are in a preparatory stage of the process of implementation through the solutions that could bring sports and physical education back to the university, both for healthy and disabled students.

Providing access to sports facilities to persons with disabilities is one of the tasks which is being successfully implemented. All newly-built sports facilities are accessible to disabled persons, while, in most of older facilities such an access has been subsequently enabled. 
The special objectives have been also specified in the Action Plan for the Strategy implementation, which envisages the local self-government units' significant participation in funding the program activities in the field of recreational and disabled sports, as well as improving the cooperation between recreational sports for persons with disabilities and school and university sports, military and police sports, workers' sports and sports in the countryside. A large number of local self-government units included the sports activities for persons with disabilities in their funding system, therefore, training session schedules, sports equipment and profesionals have been often provided at the local level, in accordance with real possibilities. The realization of these activities is often carried out by the organization of sports for all or by the DS organizations, so that it may be concluded that the task of «Ensuring institutional capacity within sports for all organizations and DS organizations for quality application of programs and projects» has been realized.

Additionally, the local self-government units are obliged to encourage and support the organization of competitions of athletes with disabilities, and they often provide scholarships to prospective disabled athletes. It has been generally accepted that a grantee of the local self-government cannot be an athlete who has been granted a scholarship by the RS Ministry of Youth and Sports, thus enabling the athletes who have not achieved internationally recognized results yet to be granted a scholarship by the local self-government units. A good estimate can be easily made exactly at the local level. Such an approach has proven to be good since the grantees often achieve significant success at the prestigious international competitions, after 2-3 years already.

A great number of users of recreational facilities provide a database for the identification and development of elite athletes with disabilities. Such facilities represent a perfect opportunity for a person to discover that they are good at a sport discipline or event, i.e. discover their inclinations and interests and to find a way to satisfy their needs, interests and desires. The Strategy has envisaged that the system of school and university sports should ensure the social integration of pupils and students with disabilities and to provide the conditions for their inclusion in the sports competition systems, therefore it may be concluded that this Strategy activity has been already implemented.
According to the Strategy it has been envisaged to carry out an analysis of the condition of recreational sports and disabled sports at the level of local selfgovernment units, and to develop recommendations and define the priorities for the functioning of disabled sports within the framework of the sports development program established in the local self-government units. A large number of local self-government units have realized this task very successfully, as evidenced by the documents available on their websites, so that this Action Plan measure may be considered implemented!

Enhancing professional potentials in recreational and disabled sports is also one of the activities that has been envisaged. Education and licensing are specific actions for the realization of this activity (Mitić, 2018). The number of licensed coaches engaged in the sports for persons with disabilities is not very high for the time being, but it is gradually increasing. The courses at the faculties of sport include this issue, professional discussions and professional meetings, seminars and conferences dealing with this issue are being held, and professional training and development plans have been prepared, therefore this activity has been also successfully realized!

\section{CONCLUSION}

In the modern world, the quality of life of persons with disabilities and the status they have in the society are considered to be an indicator of the society's development and maturity level. The experiences of many countries around the world have shown that sports activities for people with disabilities are the most successful, the most attractive, and the least expensive method of their permanent psychological and physical rehabilitation.

Disabled sports in Serbia experienced a significant expansion and development in the last decade, which is reflected by the achievement of very important sports results on the international scene, the favorable environment created for a greater inclusion of persons with disabilities in sports activities, as well as by a more precisely regulated system of organizational relations and functioning of sports clubs and associations. Additionally, the sport in Serbia has found its place in the Constitution, which was adopted in 2007, and the disabled sports have been positioned within the Ser- 
bian sports system almost equally in relation to other segments of sports.

The Sports Development Strategy in Serbia, prepared and adopted for the period from 2009 to 2013, and from 2014 to 2018, clearly defines the goals of sports development in the field of disabled sports. In order to realize the goals defined as «Improving the conditions for a greater participation of persons with disabilities in sports activities» and "Raising public awareness of the importance and role of disabled sports», a number of activities have been carried out through the implementation of specific tasks and measures.

Based on monitoring the indicators, which have been considered a benchmark for the Strategy implementation, it can be stated that the Sports Development Strategies in Serbia in the field of disabled sports have been successfully implemented. Most of the activities envisaged have been carried out, and since the Sports Development Strategy has been prepared for the period of 4 years, the successful monitoring of its effects has been ensured, as well as

\section{REFERENCES}

1. Bačanac, Lj., Milićević-Marinković, B., Kasum, G., Marinković, M. (2014). Competitive Anxiety, Self-Confidence and Psychological Skills in Top Athletes With and Without Disabilities: A Pilot Study. Facta Universitatis, 12(2), 59 - 70.

2. Vlada Republike Srbije (2014). Strategija razvoja sporta u Republici Srbiji 2014-2018. [Strategy of Sport Development in the Republic of Serbia 2014-2018. In Serbian] Službeni glasnik RS br. $1 / 2015$.

3. Valliant, P. M., Bezzubyk, I., \&Daley, L. (1990). Psychological adaptation to amputation: The role of sociodemographic variables, disability-related, factors and coping strategies. Int $J$ Rehabil Res, 22, 21-31.

4. Dausen, V. (1997). Body image of nonclinical and clinical populations of men: A literature revienj. Occup Ther Ment Health, 13, 37-55.

5. Drench, M. E. (1994). Changes in body imagiesecondary to disese and injury. Rehabil Nurs, 19, 31-36. timely correction of any deficiencies that may arise in its practical application and implementation.

Everything done in the past ten years has significantly increased the level of organization and quality of the Paralympic and Non-Paralympic sports for persons with disabilities in Serbia. The results achieved at the largest competitions are really great (Tables 1 and 2), however, in the future period, considerable efforts will be required to make this movement more mass and popular. A powerful incentive, which has been provided in this regard over the past decade, needs to be used well in planning the future activities.

\section{Note:}

The paper was created within the „Effects of the applied physical activity on the locomotor, metabolic, psychosocial and educational status of the Serbian population" project, no. III47015, and it is part of the „Effects of the applied physical activity on locomotor, metabolic, psychosocial and educational status of the population of people with disabilities in the Republic of Serbia" sub-project.

6. Generalna skupština UN (2006). Konvencija o pravima osoba sa invaliditetom. [UN Convention on the Rights of Persons with Disabilities.]. Dostupno (13.12.2019) na: https://www.osobesainvaliditetom.rs/attachments/004_Microsoft\%20 Word\%20 \%20UN_Medjunarodna\%20konvencija\%20o\%20pravima\%20osoba\%20sa\%20invaliditetom.pdf

7. Howe, P.D. (2011). Sociology. In Vanlandewijck, C.Y \& Thompson, R.W Ed: The Paralympic Athlete. IOC Publication, Chapter VI, pp 102-116. West Sussex: Weily-Blackwell.

8. Jevtić, B. (2011) Refleksija menadžmenta olimpijskih programa na sistem sporta Srbije. [Reflection of the management of the Olympic programs on the Serbian sports system]. SportLogia 7 (2) 129-140, doi 105550 / sgia110702se129J

9. Đurđević, N. (2015). Priručnik za izradu programa razvoja sporta u jedinicama lokalne samouprave. [Manual of sports development programs in local community units. In Serbian]. Beograd. Ministarstvo omladine i sporta. 
10. Đurđević, N., Đukić, I. (2016). Priručnik za finansiranje programa u oblasti sporta u jedinicama lokalne samouprave. [Manual for financing programs in the field of sports in local cpmmunity units]. Beograd: Stalna konferencija gradova i opština, Savez gradova opština Srbije.

11. Narodna skupština Serpublike Srbije (2016) Zakon o sportu. [Law on Sports. In Serbian]. Službeni glasnik RS br. 10/16.

12. Kasum, G. \& Radović, M. (2007). Analiza potreba za sportom osoba sa invaliditetom. [Analysis of needs for sports of persons with disabilities. In Serbian] U Zborniku radova sa Medunarodne naučne konferencije: "Analitika i dijagnostika fizičke aktivnosti (str. 88-97). Beograd: Fakultet sporta i fizičkog vaspitanja i Olimpijski komitet Srbije.

13. Kasum, G., \& Mijić, Z. (2009). Significance of school sports education in animation and selection of disable athletes. U International Scientific Conference "Theoretical, methodology and methodical aspects of physical education" - Conference proceedings (215-221). Belgrade: University of Belgrade - Faculty of Sports and Physical Education.

14. Kasum, G. Gligorov, S. \& Nastasić-Stošković, T. (2011). Borilački sportovi za osobe sa invaliditetom. [Combat sports for persons with disabilities]. Fizička kultura 65(1), 60-69.

15. Kasum, G. (2015). Sport osoba sa invaliditetom. [Sports disabled people. In Serbian] Beograd, Fakultet sporta i fizičkog vaspitanja.

16. Kasum, G. \& Mladenović, M. (2017). Samo-percepcija sportista sa invaliditetom. [The self-perception of athletes with disability]. Fizička kultura 71(1), 43-54.

17. Kljajić, D., Dopsaj, M., Eminović, F. \& Kasum, G. (2013). Sport u rehebilitaciji osoba sa invaliditetom. [Sport in people with disabilities rehabilitation]. Zdravstvena zaštita 42(3), 58-66.

18. Ministarstvo omladine i sporta Republike Srbije (2013). Pravilnik o nacionalnoj kategorizaciji sportova. [Rulebook on national categorization of sports. In Serbian]. Službeni glasnik Republike Srbije. 25/2013.

19. Mitić, D. (2018). Prilog za godišnji izveštaj o sprovođenju Strategije razvoja sporta u Republici Srbiji.[Annex to the annual report on the imple- mentation of the Strategy for the Development of Sport in the Republic of Serbia. In Serbian] Beograd, Dokument, Fakultet sporta i fizičkog vaspitanja.

20. Mićović, Z. (2014). Paraolimpijski komitet Srbije. [Paralympic Committee of Serbia. In Serbian]. Dostupno (30.9.2017) na http://www.paralympic. rs/organizacija/predsednik

21. Ministarstvo omladine i sporta Republike Srbije (2008). Strategija razvoja sporta u Republici Srbiji 2009-2013. [Strategy of Sport Development in the Republic of Serbia 2009-2013. In Serbian]. Službeni glasnik Republike Srbije 110/2008.

22. Ministarstvo omladine i sporta Republike Srbije (2009). Akcioni plan za sprovođenje Strategije razvoja sporta u Republici Srbiji 2009-2013 godine. [Action Plan for Implementation of the Strategy for the Development of Sport in the Republic of Serbia 2009-2013. In Serbian]. Beograd: Ministarstvo omladine i sporta.

23. Nacionalni sportski savez slepih i slabovidih (2018). O Nama. [About us. In Serbian]. Dostupno (4.2.2018) na http://nssss.co.rs/o-nama.php

24. Orlić, A., Pejčić, B., Lazarević, D., \& Milanović, I. (2016). Prediktori stava studenata prema inkluziji dece sa razvojnim smetnjama u nastavu fizičkog vaspitanja. [The predictors of students' attitude towards inclusion of children with disabilities in physical education classes]. Fizička kultura 70(2),126-134.

25. World Taekwondo Europe Solidarity and Parataekwondo Committee (2013). Results. Dostupno (5.3.2019) na http://worldtaekwondoeurope. com/results

26. Sportski savez Srbije. Publikacije. Dostupno (4.2.2018.) na http://www.serbiansport.com/publikacije

27. Pokrajinski sekretarijat za sport i omladinu (2008). Sport osoba sa invaliditetom. Strategija razvoja sporta u AP Vojvodina (103-112). [Sports disabled people. Sport Development Strategy in AP Vojvodina. In Serbian]. Novi Sad. Dostupno (11.9.2017.) na http://njnjnj.sio.vojvodina.gov. rs/indedž.php/sport/sport-za-sve/8-sport/225strategija-razvoja-sporta-u-ap-vojvodini

28. Službeni glasnik Republike Srbije (2006, 2007 и 2009). Uredba o nacionalnim priznanjima i nagradama za poseban doprinos razvoju i afirmaci- 
ji sporta. [Regulation on national recognitions and awards for a special contribution to the development and affirmation of sports. In Serbian]. Službeni glasnik Republike Srbije 65/06, 6/07, 24/09 и 88/09.

29. Sportski savez gluvih Srbije (2015). Strategija razvoja sporta gluvih u periodu 2015-2018 godina. [Strategy for the development of deaf sports in the period 2015-2018. In Serbian]. Dostupno (15.9.2017.) na http://njnjnj.ssgs.rs/Strategija $\% 20$ razvoja $\% 20$ sporta $\% 20$ gluvih\% $20 \mathrm{u} \% 20$ periodu\%202015\%20\%202018.\%20godine.pdf

30. International Table Teniss Federation, Para Table Teniss. Tournaments (2012-2016). Dostupno (11.2.2018.) na http://stats.ipttc.org/tournaments

31. Ministarstvo omladine i sporta Republike Srbije (2016.). Pravilnik o sportskim granama i oblastima sporta u Republici Srbiji i sportskim disciplinama u sportskim granama i oblastima sporta. [Rulebook on sports branches and areas of sports in the Republic of Serbia and sports disciplines in sports branches and sports fields. In Serbian]. Službeni glasnik RS 51/16. Beograd:

32. Ministarstvo omladine i sporta Republike Srbije (2016). Pravilnik o sportskim granama od posebnog značaja za Republiki Srbiji. [Rulebook on sports branches of special importance for the Republic of Serbia. In Serbian]. Službeni glasnik Republike Srbije 95/16.

33. Šiljak, V., Stefanović, Đ., Plakona, E., Kasum, G. \& Avdibašić-Vukadinović, N. (2010). Fenomen Letnjih paraolimpijskih igara. [Summer Paralympic games phenomenon]. Fizička kultura 64(2), 68-75.

34. Winnick, J. R. (1995). Adapted Physical Education And Sport. USA, State University of Nenj York College at Brockport: Human Kinetics. 


\title{
СПОРТ ОСОБА СА ИНВАЛИДИТЕТОМ - КОРАЦИ КА СМАҢЕЊУ ИСКЉУЧЕНОСТИ И НОВОЈ ВРЕДНОСНОЈ ПАРАДИГМИ СРПСКОГ ДРУШТВА
}

\author{
Горан Касум \\ Факултет спорта и физичког васпитања, Универзитет у Београду, Србија
}

\begin{abstract}
Сажетак
Спорт особа са инвалидитетом (СОИ) у Србији током последње деценије доживљава развој, који се огледа не само у постизањузначајних спортских резултата на међународној сцени, већ, и пре свега, кроз стварање повољног амбијента за веће укључивање особа са инвалидитетом у спортске активности. Промене које трају одвијају се и као организациона прекомпозиција система параолимпијског спорта кога, данас, одсликава прецизније уређен систем, организационои технолошко повезивања свих чинилаца самог покрета и друштва, као и ефикасније функционисања клубова и спортских удружења. За унапређење и развој спорта особа са инвалидитетом посебно језначајно то што је финансирање доласка до врхунских резутата преузела централна држава. Са друге стране, услове за масовно и рекреативно бављење спортом особама са инвалидитетом треба да обезбеде јединице локалне самоуправе.Опоравак и оздрављење спорта у Србији, самим тимеи спорта особа са инвалидитетом, поклапа се са усвајањем Устава (2006), доношењемзакона о спорту (2009 и 2016), као и реализацијом два циклуса националне стратегије развоја спорта (2009-2013 и 2014-2018). Опредељење да се стратегија развоја спорта ради за период од 4 године, створило је могућности да промене не буду сувише инвазивне, да се обезбеди косензус свих чинилаца битних за њену реализацију, као и да се континуирано прате њени ефекти са мерамаза корекцију свега што је у реалној примени наишло на проблеме.На основу праћењаиндикатора спровођења Стратегије, могуће је констатовати да се она у простору спорта особа са инвалидитетом ефикасно реализује, те да јевећина активности предвиђених акционим планом успешно спроведена.
\end{abstract}

КљУчне речи: СПОРТ ОСОБА СА ИНВАЛИДИТЕТОМ/НАЦИОНАЛНАСТРАТЕГИЈА / ВРЕДНОСТИ / ДРУШТВЕНИ РАЗВОЈ / СРБИЈА

\section{ПАРАОЛИМПИЈСКИ СПОРТ У ПРОМОЦИЈИ ПРАВА ОСОБА СА ИНВАЛИДИТЕТОМ}

Параолимпијски покрет започео је свој живот као спортско такмичење које је педесетих година 20. века одржавано у Сток Мендвилу у Енглеској и на коме су учествовали ветерани Другог светског рата са повредом кичменог стуба. Након ових почетних такмичења, расла је међународна пажња према особама са инвалидитетом, да би се у Риму 1960. године организовале Прве званичне олимпијске игре за спортисте са инвалидитетом. Бављење спортом омогућава особама са инвалидитетом да побољшају своје физичко,социјално, афективно ифункционално здравље, рехабилитацију учине ефикаснијом, да имају садржајан живот... Зато се рекреативно или такмичарско бављење спортом врло „гласно“ препоручује као једна врста терапије, али и као стил живота.

Учешћем у спорту постиже се хуманизација социјалних односа за значајан број грађана, чини и велика уштеда у друштвеном буџету, јер уместо да се задржавају унутар породице, бораве у болницама или санаторијумима, особе 
са инвалидитетом које се баве спортом иду ка осамостаљењу, врло често заснивају породицу, а као врхунски спортисти постају познати и популарни у јавности. Ако се има у виду чињеница да је један од приоритета у раду са особама са инвалидитетом сталниподстицајда буду јаки духом, да се успешно укључе у друштво и да прихвате да могу много да постигну у животу, онда управо животне приче и успеси спортиста са инвалидитетом представљају одличан пример етичких и моралних вредности једног друштва и путоказ свим његовим грађанима како се треба носити са животним изазовима и тешкоћама.

Сјајни успеси параолимпијаца подстичу ширењеспортског духа, али, и пре свега, воде ка смањењу стигматизације у друштву, подстичу развој параолимпијског покрета на националном нивоу уз опште прихваћену констатацију да не морају сви бити врхунски спортисти, алиће бављење спортом свима и те како користити.У правој академској расправи са темом националне проблематике спорта инвалида као предмета овог рада, треба истаћи да су се у Србији, у периоду од 2006.одвијале многе промене у системском и вредносном преобликовању параолимпијског покрета и укупно спорта особа са инвалидтитетом. Промене су биле иницирне од самог СОИ, али и политичких нивоа централне државе и самог система спорта. Оне су пратиле агенду која је усвојена како унутар међународних спортских форума, тако и на нивоу политичких одлука Европске уније (ЕУ), Савета Европе (СЕ) или агенција Уједињених нација (УН). На нивоу ЕУ донета су политичка документа и резолуције о простору спорта и социјалне укључености свих грађана са исходима и на простор СОИ (2011), отворени су фондови за подршку процесу социјалне инклузије. Европска унија стреми јачању недискриминаторне стране европских закона и правила, усваја принципе и акциони план Стратегије за особе са инвалидитетом (20102020) и Стратегије за једнакост (2010-2015). Цео процес је успостављен на осам принципа који се налазе унутар Конвенције о правима особа са инвалидитетом (Генерална скупштина УН, 13.12.2006), а коју је Србија потписала 31. јула 2009. године. Према овој Конвенцији, особе са инвалидитетом су лицакоја дугорочно имају физичка, ментална, интелектуална или сензорна оштећења, која у интеракцији са различитим баријерама могу ометати њихово пуно и ефикасно учешће у друштву на равноправној основи са другима. Принципи на којима је заснована Конвенција УН су:

- поштовање урођеног достојанства и индивидуалне аутономије, укључујући слободу сопственог избора и пуне независности ових особа,

- недискриминација,

- пуна и делотворна партиципација и укључивање у друштво,

- поштовање различитости и прихватање особа са инвалидитетом као дела људске разноликости и човечности,

- једнакост могућности,

- приступачност,

- једнакост између мушкараца и жена, и

- поштовање развојности капацитета деце са сметњама у развоју и поштовање права деце са сметњама у развоју ради очувања њиховог идентитета.

Манифестни облик СОИ су параолимпијске игаре које су засноване на традицији фер и часног спортског такмичења. Вредности параолимпијског покрета су важније него у било ком другом облику спорта, и то су:

храброст која обухвата јединствени дух параолимпијских спортиста, који настоји да постигне оно што општа јавност сматра неочекиваним, али за шта спортиста зна да је могуће;

одређење као излагање идеје да спортисти померају своје способности до апсолутне границе;

инспирација која причамао достигнућу спортиста креира интензивну и личну наклоност других према параолимпијцима, а ефекат њиховог духа примењује на сопствени живот;

једнакост која параолимпијски спорт усмерава као средство за промене, да се отколне социјалне баријере и дискриминације особа са инвалидитетом.

У истом периоду и у Србији се у простору параолимпијског покрета одвија анализа спортских и политичких докумената и резолуција УН, CE, ЕУ, и отпочиње са(пре)уређењем система СОИ, његово организационои технолошко повезивања које треба да доведе до трајних вредности и легата за укупни развојсрпског друштва,а то је увећана инклузија кроз обухват и ефикасније функционисања клубова и спортских удружења особа са инвалидитетом. 


\section{ПАРАОЛИМПИЈСКИ ПОКРЕТ - ВРЕДНОСНО ПРЕОБЛИКОВАҢЕ СРПСКОГ ДРУШТВА}

Прве параолимпијске игре су, под службеним називом „9th Annual International Stoke Mandeville Games“, одржане 1960. године у Риму. Спортистинекашње СФРЈ по први пут су учествовали 1972. године и све до распада ове државне заједнице бележени су врло запажени резултати. Након распада СФРЈ, у Србији је дошло до кризе резултата у целокупном спорту, па и у спорту особа са инвалидитетом. Лоша материјална ситуација, међународне санкције у спорту (1992-1995), слаба организованост и, пре свега, мањак правих покретачких вредности и мотива, довелису до тога да је за наше спортисте са инвалидитетом успех представљао и сам одлазак на такмичење. Често се дешавало отказивањеучешћа на светском или европском првенству, само пар дана пре поласка, а када би се на такмичење ипак отишло, то је већ представљало значајан напредак. Наравно, у таквим околностима успеси су изостајали, а медаље које су освојене заправо су представљале својеврстан подвиг појединца, а не резултат неког озбиљног и организованог рада. У последњих десетак година, параолимпијски спорт у Србији доживљава значајну експанзију и бележи сјајне резултате. Најширој јавности је познато да је на Параолимпијским играма у Рију 2016. године освојено 9 медаља (3 златне, 2 сребрне и 4 бронзане), да је у Лондону 2012. освојено 5 медаља (2 златне и 3 сребрне), докостали многобројни велики успеси наших спортиста са инвалидитетом на великим такмичењиманису интензивно промовисани и пропраћени кроз медије. Само у параолимпијским спортовима и њиховим дисциплинама, у последњих 12 година освојено је 153 медаље (Табела 2), док је у непараолимпијским спортским гранама и дисциплинама освојено још 217 медаља (Табела 1). Наши параолимпијци из године у годину освајају велики број медаља на светским и европским првенствима, а нарочито су успешни у стоном тенису (Tournaments, 20122016), стрељаштву и атлетици (Публикације, 2017), а последњих неколико година и у теквондоу (Results, 2013). Спортски успеси српских спортиста са инвалидитетом, остварени од 2009. до 2012. године, значано су допринели афирмацији параолимпијског покрета и бољем позиционирању параолимпијских спортова у друштву (Мићовић, 2014), па није изненађење што је у последњих 6 година, само у параолимпијским спортским гранама и дисциплинама, број освојених медаља постао троцифрен. Укупан број освојених медаља у параолимпијским дисциплинама у периоду 2007-2012. године износи 53 , од чега 22 са ПОИ и светских првенстава, a 31 са европских првенстава, док је од 2012. до 2018. освојено 100 медаља, од чега 29 са ПОИ и светских превенстава, а 71 са европских првенстава (Табела 2). Сличан тренд уочава се и код непараолимпијских спортских грана. Од 2007. до 2012. освојено је 60 медаља, од чега 37 на светским и 23 на европским првенствима, а од 2012. до 2018. чак 157 медаља, 75 на светским и 82 на европским првенствима (Табела 1). Оваква експанзија спортских успеха у последњој декади, са уочљивом тенденцијом сталног пораста броја освојених медаља, обавезује да се подсетимо фактора који су омогућили тај опоравак спорта особа са инвалидитетом, али и да се анализом самог система издвоје проблеми у организационој ефикасности, те да се на основу тих анализа приступи афирмацији спорта у функцији „оздрављења“ друштва - његове дестигмитизације. 
Касум Г., Спорт особа са инвалидитетом..., ФИЗИЧКА КУЛТУРА 2019; 73 (1): 23-39

Табела 1 Медаље у непараолимпијским спортским гранама и дисциплинамаосвојене у периоду 2007-2018.

\begin{tabular}{|c|c|c|c|c|c|c|c|c|}
\hline \multirow{3}{*}{$\begin{array}{c}\text { ТАКМИ- } \\
\text { ЧЕЊЕ } \\
\text { Год. }\end{array}$} & \multicolumn{7}{|c|}{ СВЕТСКА ПРВЕНСТВА } & \multirow{3}{*}{ укУПно } \\
\hline & \multicolumn{2}{|c|}{ Пласман } & \multicolumn{5}{|c|}{ Пласман } & \\
\hline & $\begin{array}{c}\text { Инвалидитет и спортска } \\
\text { грана } \\
\end{array}$ & I & II & III & I & II & III & \\
\hline 2007 & Глуви & & & & 1 & & 2 & 3 - Рвање \\
\hline \multirow{4}{*}{2008} & Глуви & & & 2- Шах, Рвање & 1-Рукомет & & & 3 \\
\hline & $\begin{array}{l}\text { Специјална } \\
\text { олимпијада }\end{array}$ & & & & $\begin{array}{l}\text { 2-Фудбал } \\
\text { Кошарка }\end{array}$ & & & 2 \\
\hline & Слепи и слабовиди & & & & & 1 & 1 & 2-Куглање \\
\hline & Бодибилдинг & 1 & & & 1 & & & 2 \\
\hline \multirow{3}{*}{2009} & Глуви & & 1- Рукомет & 1-Стрељаштво & & & & $2 \mathrm{OИ}$ \\
\hline & Специјална олимпијада & 8 & 7 & 3 & & & & 18 Зимска \\
\hline & World Dwarf Games & 1 & 1 & & & & & 2- Пливање \\
\hline \multirow{3}{*}{2010} & Специјална олимпијада & & & & 4 & 2 & 4 & 10 \\
\hline & Глуви & & 1 - Шаx & & & & & 1-Шах. Олимп. \\
\hline & Стрељаштво & & & 1 & & & & 1 \\
\hline \multirow{5}{*}{2011} & IBSAСлепи и слабов. & 1 & 1 & & & & & 2- Атлетика \\
\hline & $\begin{array}{l}\text { IWAS }^{*} \text { Игре спортиста у } \\
\text { колицима и ампутац. }\end{array}$ & 1 & 1 & & & & & 2- Атлетика \\
\hline & Тријатлон & & & & 1 & & & 1 \\
\hline & Слепи и слабовиди & 1 & & 1 & & & & 2-Куглање \\
\hline & Слепи и слабов.јуниори & 1 & & 1 & & & & 2-Шах \\
\hline \multirow{3}{*}{2012} & Глуви & 1 шах & & & & & 1-Рукомет & 2 \\
\hline & Триатлон & & 1 & & & 1 & & 2 \\
\hline & Специјална олимпијада & & & & & 1 -Фудбал & & 1 \\
\hline & Купно (2007-2012 & 15 & 13 & 9 & 10 & 5 & 8 & 60 \\
\hline \multirow{6}{*}{2013} & Глуви & & 1- Рукомет & 1-Стрељ. & & & & 2 ОИ глуви \\
\hline & Слепи и слабовиди & & & & 1 & 1 & 3 & 5- Куглање \\
\hline & Стрељаштво & & & & 1 & 2 & 3 & 6 \\
\hline & Слепи и слабов.јуниори & & 1 & 1 & & & & 2-Шах \\
\hline & Специјална олимпијада & $\begin{array}{c}\text { 6- } \\
\text { Зимска }\end{array}$ & $\begin{array}{c}5 \\
\text { Зимска }\end{array}$ & $\begin{array}{c}6 \\
\text { Зимска }\end{array}$ & $\begin{array}{c}\text { 2- Фудбал, } \\
\text { Кошарка }\end{array}$ & 1 -Одбојка & & 20 \\
\hline & World Dwarf Games & & 2 & & & & & 2 -Пливање \\
\hline \multirow{5}{*}{2014} & Глуви & & & 1- Рукомет & & & & 1 \\
\hline & Слепи и слабовиди & & & & 1 & & 1 & 2- Куглање \\
\hline & Стрељаштво & & 1 & & & & & 1 \\
\hline & Тријатлон ${ }^{* *}$ & & & 1 & & & & 1 \\
\hline & Специјална олимпијада & & & & 9 & 7 & 11 & 27Летња \\
\hline \multirow{4}{*}{2015} & глуви & & & & & 1 & 1 & 2- Стрељ. \\
\hline & Слепи и слабовиди & 1 & & 1 & & & & 2- Куглање \\
\hline & Слепи и слабов.јуниори & 1 & & & & & & 1 - Шах \\
\hline & Спец. олимп. & 6 & 6 & 5 & & & & 17 Летња \\
\hline \multirow{3}{*}{2016} & Теквондо & & & & & 2 & 4 & 6 \\
\hline & Слепи и слабовиди & & & & 1 & 2 & 2 & 5- Куглање \\
\hline & Глуви & & & 1 & & & & 1- Стрељ. \\
\hline
\end{tabular}


Касум Г., Спорт особа са инвалидитетом..., ФИЗИЧКА КУлТУРА 2019; 73 (1): 23-39

\begin{tabular}{|c|c|c|c|c|c|c|c|c|}
\hline \multirow{5}{*}{2017} & Специјална олимпијада & 6 & 9 & 6 & & & & 21 Летња \\
\hline & Глуви & & & & 1 & & & 1-Шаx \\
\hline & Слепи и слабовиди & & & & 2 Куглање & & & 2 \\
\hline & Теквондоформе & & & 2 & 1 & 1 & $3(1-$-јун $)$ & 7 \\
\hline & Теквондоборбе & 1 & 2 & & 2 & & 2 & 7 \\
\hline \multirow{6}{*}{2018} & Карате (слабовиди) & & & & & 1 & & 1- Кате \\
\hline & Стрељаштво & 1 екипа & & & 1 екипа & & 1 екипа & 3 \\
\hline & Глуви & 1 шах. ол. & & & & & & 1- Екипно \\
\hline & Теквондо & & & & $\begin{array}{c}3 \\
\text { (2- јуниори) }\end{array}$ & & 2 & 5-Форме \\
\hline & Теквондоборбе & & & & 2 & 2 & 1 & 5 \\
\hline & Слепи и слабовиди & & & & & 1 & & 1-Куглање \\
\hline \multicolumn{2}{|c|}{ Укупно (2013-2018) } & 23 & 27 & 25 & 27 & 21 & 34 & 157 \\
\hline \multicolumn{2}{|c|}{ УКУПНО (2007-2018) } & 38 & 40 & 34 & 37 & 26 & 42 & 217 \\
\hline
\end{tabular}

* Применом Уредбе о националним признањима и наградама за посебан допринос развоју и афирмацији спорта, која је усвојена 2. априла, а спроведи се од децембра 2009. године (Службени гласник РС бр. 24/09 и 88/09, 2009), прецизирано је да се светским и европским првенствимау параолимпијским атлетским дисциплинама сматрају искључиво такмичења у организацији IPC Athletcs (od 2017. World Para Athletics), који је подкомитет Међународног параолимпијског комитета задужен за атлетику. Тиме су, од 2010. године европска и светска првенства у организацији International Blind Sports Federation (IBSA) и International Wheelchair and Amputee Sports Federation (IWAS) практично постале непараолимпијске дисциплине.

** Тријатлон се на програму ПОИ први пут нашао 2016. године, али дисциплина у којој је Лазар Филиповић освојио медаљу на Светском првенству није била део програма за мушкарце, већ само за жене, па је у овом прегледу тај успех сврстан у неолимпијске дисциплине.

Табела 2 Медаље у параолимпијским спортским гранама освојене у периоду 2007-2018.

\begin{tabular}{|c|c|c|c|c|c|c|c|c|}
\hline \multirow{3}{*}{$\begin{array}{l}\text { ТАКМИЧЕЊЕ } \\
\text { Год. }\end{array}$} & \multicolumn{4}{|c|}{ СВЕТСКА ПРВЕНСТВА } & \multicolumn{3}{|c|}{ ЕВРОПСКА ПРВЕНСТВА } & \multirow{3}{*}{ УКУПНО } \\
\hline & \multicolumn{2}{|c|}{ Пласма } & \multicolumn{5}{|c|}{ Пласма } & \\
\hline & Грана спорта & I & II & III & I & II & III & \\
\hline \multirow[b]{2}{*}{2007} & Стони тенис & & & & 1 & 1 & 1 & 3 \\
\hline & $\begin{array}{c}\text { IBSA }^{* * *} \text { Слепи и } \\
\text { слабовиди }\end{array}$ & & & 2 & & & & $\begin{array}{c}2 \text { - } \\
\text { Атлетика }\end{array}$ \\
\hline 2008 & $\begin{array}{l}\text { ПОИатлетика, } \\
\text { стони тенис }\end{array}$ & & 2 & & & & & 2 \\
\hline 2009 & IWAS $^{* * *}$ Колица & 1 & 2 & 1 & & & & 4-Атлетика \\
\hline \multirow{4}{*}{2010} & Стони тенис & & & & 2 & 1 & 2 & 5 \\
\hline & Атлетика & & & & 3 & 4 & 3 & 11 \\
\hline & Стони тенис & & 1 & 2 & & & & 2 \\
\hline & Стрељаштво & 1 & & & & & & 1 \\
\hline \multirow{2}{*}{2011} & Атлетика & 1 & 3 & 1 & & & & 5 \\
\hline & Стони тенис & & & & 3 & 1 & 1 & 5 \\
\hline \multirow[b]{2}{*}{2012} & Атлетика & & & & 5 & 1 & 2 & 8 \\
\hline & ПОИ & 2 - Атлетика & $\begin{array}{c}3 \text { (атлет -1, } \\
\text { ст. тенис- } \\
2 \text { ) }\end{array}$ & & & & & 5 \\
\hline Укупн & 007-2012) & 5 & 11 & 6 & 14 & 8 & 9 & 53 \\
\hline
\end{tabular}


Касум Г., Спорт особа са инвалидитетом..., ФИЗИЧКА КУЛТУРА 2019; 73 (1): 23-39

\begin{tabular}{|c|c|c|c|c|c|c|c|c|}
\hline \multirow{3}{*}{2013} & Стони тенис & & & & 1 & 1 & 2 & 4 \\
\hline & Стрељаштво & & & & 2 & 1 & 2 & 5 \\
\hline & Атлетика & & 1 & & & & & 1 \\
\hline \multirow{3}{*}{2014} & Стрељаштво & & 1 & & & & & 1 \\
\hline & Атлетика & & & & & 5 & 1 & 6 \\
\hline & Стони тенис & 1 & & 3 & & & & 4 \\
\hline \multirow{3}{*}{2015} & Атлетика & 1 & 2 & 2 & 1 & 2 & 1 & 9 \\
\hline & Стони тенис & & & & 1 & 2 & 1 & 4 \\
\hline & Powerlifting & & & & & 1 & & 1 \\
\hline \multirow[b]{3}{*}{2016} & Триатлон & & & & 1 & 2 & 1 & 4 \\
\hline & Атлетика & & & & 2 & 2 & 2 & 6 \\
\hline & пои & $\begin{array}{l}3 \text { (атлетика, } \\
\text { стрељ. } \\
\text { стони } \\
\text { тенис) }\end{array}$ & $\begin{array}{c}2 \text { (атлетика } \\
\text { стони } \\
\text { тенис). }\end{array}$ & $\begin{array}{l}4(\text { атлетика- } 1, \\
\text { стрељаштво-. } 1 \\
\text { стони тенис -2) }\end{array}$ & & & & 9 \\
\hline \multirow{8}{*}{2018} & Стони тенис & 1 - екип Ж & & 1- екип. M & 2 & & 4 & 8 \\
\hline & Атлетика & 2 & & 1 & 2 & & 4 & 9 \\
\hline & Теквондо **** & & & 2 & & 1 & 2 & 5 \\
\hline & Атлетика ${ }^{* * * * *}$ & & & & 3 & 2 & 8 & 13 \\
\hline & Стони тенис & 1 & & & & & & 1 \\
\hline & Стрељаштво & 1 & & & 1 & 1 & & 3 \\
\hline & Теквондо & & & & & 3 & 3 & 6 \\
\hline & Бадминтон & & & & & & 1 & 1 \\
\hline \multicolumn{2}{|c|}{ Укупно (2013-2018) } & 10 & 6 & 13 & 16 & 23 & 32 & 100 \\
\hline \multicolumn{2}{|c|}{ Укупно (2007-2018 } & 15 & 17 & 19 & 30 & 31 & 41 & 153 \\
\hline
\end{tabular}

*** Прва верзија Уредбе о националним признањима и наградама за посебан допринос развоју и афирмацији спортаиз јуна 2006. године (Службени гласник РС бр. 65/06, 2006) односила се само на олимпијске и параолимпијске игре, да би јанура 2007. она била проширена на светска и европска првенства у олимпијским и параолимпијским спортовима (Службени гласник РС бр. 6/07, 2007). Овом Уредбом није било прецизирано на која такмичења и које дисциплине се она односи, па су сва светска и европска атлетска првенства, која су организовалиInternational Paralympic Committee Athletics (IPC Athletics), International Blind Sports Federation (IBSA) и International Wheelchair and Amputee Sports Federation (IWAS), као и све такмичарске дисциплине сматране параолимпијским спортом.

**** Теквондо ће ce, као параолимпијски спорт, први пут појавитина ПОИу Токију, а једина параолимпијска дисциплина биће борбе за такмичаре са инвалидитетом горњих екстремитета (К40), и то само у класама +К43 (К43 и К44). Због тога су резултати остварени у дисциплини Форме, као и Борбе у класама К41 и К42, сврстани у напараолимијске дисциплине.

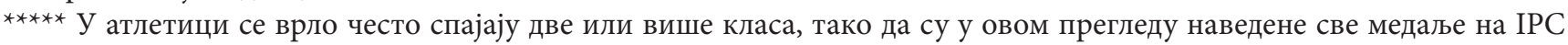
Athletics првенствима Европе и света, без обзира на то да ли је та такмичарска класа била на програму следећих параолимпијских игара. Примера ради, од 13 медаља са Првенства Европе 2018. године, 10 је у класама које ће такмичити у Токију,али су и преостале 3 медаље освојене у класама које су током последње деценије биле на програму ПОИ, па неће бити ништа необично ако неке од те три класе буду део званичног програма ПОИ у Паризу. Иначе, када се нека класа споји са вишом класом, то значи да ће тим спортистима бити пуно теже да дођу до медаље јер ће им конкуренцију чинити и спортисти са мањим степеном инвалидитета, односно спортисти који имају веће способности. 


\section{ТАКМИЧАРСКИ ИСХОДИ СПОРТИСТА СА ИНВАЛИДИТЕТОМ И}

\section{ПРОЦЕС ДЕСТИГМАТИЗАЦИЈЕ СРПСКОГ ДРУШТВА}

Велики број аутора, који се баве проблематиком спорта и физичке активности особа са инвалидитетом, истичу њихов велики значај за ову популацију људи (Dausen, 1977; Drench, 1994; Valliant, Bezzubyk, \& Daley, 1990; Winnick,1995). У литератури су детаљно образложене негативне последице које прате продужено мировање, али и позитивни ефекти физичких активности на психо-физичко стање организма (Касум, 2007; Бачанац и сар., 2014). Спорт и физичко вежбање представљају добар животни терен за развој позитивне самоперцепције, а особе са инвалидитетом са годинама постају сналажљивије у различитим животним ситуацијама (Касум и Младеновић, 2017). Упркос овим недвосмисленим порукама које носе и позитиван печат научне верификације, до пре неколико година релативно мали број особа са инвалидитетом у Србији биоје укључен у спортске активности. У Савезу за спорт и рекреацију инвалида Србије је 2009. године било регистровано око 17000 спортиста са инвалидитетом, што је представљало тек нешто више од $2 \%$ укупног броја особа са инвалидитетом у Србији. Верује се дани тај број није био реалан, јер многи регистровани спортисти нису били истински укључени у спортске активности, већ су само били „административна чињеница“ (Касум и Мијић, 2009). Проценат особа са инвалидитетом које су укључене у спортске активности се разликује у односу на регион и локалну заједницу у којој живе и тренирају, али, важно је истаћи да се овај број у значајној мериразликовао и у зависности одврсте инвалидитета. Тако је у Новом Саду у спортске активности било укључено $12 \%$ популације особа са менталним заостајањем, а свега 3\% особа са телесним инвалидитетом (РСАП Војводина, Покрајински секретаријат за спорт и омладину, 2008).

Један од главних разлога за овакво учешће, које се свакако не може оценити као велико, јесте недовољно развијена свест о неопходности спортских активности, како код самих особа са инвалидитетом тако и код чланова њихових породица.Управозато је, као један од највећих приоритета развоја спорта у области СОИ,апострофирано подизање друштвене свести о значају и улози СОИ. Ово представља дугорочан задатак, на којем се мора радити константно и систематски.

Правна регулатива која прати област СОИ се мења далеко лакше и брже, па се показало да је много лакше отклонити евентуалну законску препреку за масовније укључивање особа са инвалидитетом у спортске активности, него променити ставове и начин размишљања на ову тему. Општи је закључак да су позитивни ставови околине један од пресудних услова за масовније укључивање особа са инвалидитетом у спортске активности (Орлић и сар., 2016). Са подизањем друштвене свести, постепено се увећава и број клубова спортиста без инвалидитета у којима је спортистима са инвалидитетом омогућено да се баве спортом. Овај процес се одвија у два смера, па већа спремност околине да прихвати и подржи спортско ангажовање особа са инвалидитетом чини да се оне лакше укључују у спортске активности, док, садругестране, њихова масовнија укљученост чини да се окружењепривикава и са нескривеном подршком и одобрава овај процес.

У пракси се примећује и агилнији приступ неких јединица локалне самоуправе (ЈЛС) овом проблему. Тако клуб који жели да повуче одређена средства на основу резултата спортисте са инвалидитетом, мора бити регистрован за дисциплине СОИ, а приоритет у финасирању имају програми који подстичу ове активности. Многи тренери и стручњаци у спорту своју афирмацију, али и професионалну оријентацију, проналазе управо захваљујући свом опредељењу да припремају спортисте са инвалидитетом. Све је већи број клубова у којима су квалитетни спортисти са инвалидитетом пронашли своје место у екипама такмичара без инвалидитета, што свакако представља велики бенефит оваквог начина рада. Има примера да особе са инвалидитетом постају првотимци локалних клубова, а понекад чак и државни репрезентативци. Успеси које спортисти са инвалидитетом остварују доносе значајне личне благодети, али од тога непосредан или посредан бенефит имају и њихове породице, тренери и спортски радници, радне организације, остале 
особе са инвалидитетом, али и друшвена заједница у целини. Једном речју, српско друштво је напредовало у медицини и хирушким оперативним захватима, којима је могуће отклонти или умањити степен биомедицинског инвалдитета, али је створило и могућности за интегралну рехабилитацију кроз спорт. Приметна су настојања увођења прилагођених форми спорта (нпр. спорт у колицима), али и модификација и хуманизација архитектонских баријера којима је испуњена средина у којој живимо. Србија процесно, можда не и са тако високим интензитетом, као што то чине земље ЕУ, иде ка дестигматизацији свог друштва и настоји да буде добро место за живот свих њених грађана!

Многобројни позитивни ефекти од бављења спортом, које осете особе са инвалидитетом, допринели су томе да већина оних који се укључе у спортске актвности ту навику задржавају дуги низ година. Није реткост да се појединци опробају у више спортова, често и да се такмиче у неколико спортских дисциплина, а понекад чак и у потуно различитим спортским гранама. Међутим,и даље највећи проблем представља сам почетак њиховог бављењаспортом, који сенајчешће везује за неки случајан сусрет са тренером или другим спортистом са инвалидитетом. Приче о таквим сусретима најчешће звуче доста интересантно, али и указују на проблем суздржаности, лоше информисаности и организованости особа које имају неки облик инвалидитета. Ово би се могло исказати каолични факторкоји ограничава њихову укљученост у друштво! Заправо, изгледа као да је највећи проблем да се особе са инвалидитетом укључе у спорт баш лични чинилац, јер, анализа учињеног у периоду за нама указуједа су за њихово даље спортско усавршавања обезбеђени добри услови. Једном речју, дошло је време целовитијег и хуманијег друштвеног разумевања проблема инвалидитета.

Један од разлога изостанка ових појединца из спорта налази се и у лошој повезаности између процеса наставе физичког васпитања, како у редовним, тако и у специјализованим школама, као и њихово укључивање у тренажне и такмичарске активности, како у редовном спорту тако и у простору алтернативног и иновативног спорта особа са инвалидитетом. Управо зато, као један од битних праваца развоја ових појединаца кроз спорт, мора бити њихово укључивање у школски и универзитетски спорт, где је, уз релативно мала улагања, могуће постићи значајне резултате у погледу квантитета али и квалитета спорта особа са инвалидитетом. Деца и омладина са инвалидитетом благовремено укључена у реализацију оваквих програма имала бивећи осећај сигурности, самопоштовања и емоционалне контроле, успешнијеби развила своје способности, комуникацију, осетљивости за потребе других и бољу социјализацију (Howe, 2011). Њиховим родитељима би сепружила прилика да боље упознају могућности и способности своје деце, развијају вештину њиховог подстицања, али и развијају реалистичне ставове према тренутним могућностима и будућности свогдетета.Није на одмет рећи да је циљ спорта, у првом кораку учешће, али да се не сме занемарити значај спорта којим би се њихов инвалидитет учинио мање ограничавајућим. Деца из редовне популације прихватају различитости као нешто природно и развијају емпатију за потребе деце са инвалидитетом. Користи од овако организованих спортских активности имали бии родитељи деце без инвалидитета, наставници у школи, тренери, али и сви они који су директно или индиректно укључени у ове процесе. Овакви приступи и инклузивни програми спорта посебно су корисни и значајани за децу са одређеним заостатком моторике (Касум, \& Мијић, 2009).

Животне приче већег броја наших врхунских спортиста параолимијаца, али и неких од највећих светских спортиста са инвалидитетом, представљају својеврсну апотеозу о инклузији и на најбољи могући начин пропагирају ову идеју. Менаџмент биографија успешних, садржи мере које треба да доведу до смањења искључености и подстакну инклузију. Вредност и значај идеје о инклузији наилази на све веће разумевање и прихватање, али за њену надоградњу и усавршавање остаје пуно простора. Непосреднија и конкретнија повезаност између реализације наставе физичког васпитања и укључивања у спортске клубове представља логичан корак унапређења ове изузетно квалитене и напредне идеје.Ипак, истине ради, инклузија се не сме и не може посматрати као специфично питање и проблем спорта. Она је више и значајније резултат социјалне ситуације о којој сва друштва, па и српско, морају да воде отворен и конструктиван дијалог. 
Сјајни успеси које наши параолимпијци постижу на међународној сцени, истовремено суи показатељ бриге друштва о популацији особа са инвалидитетом, а степен бриге о особама са инвалидитетом један је од најпроминентнијих показатеља степена развијености једног друштва. У савременом свету се однос и брига друштва према мањинским групама, у које спадају и особе са инвалидитетом, сматра мером развијености тог друштва. Спортски успеси, које су у протеклој декади постигли српски параолимпијци,врше веома значајну промоцију нашег друштва, и чине дасвету шаљемо лепу и афирмативну слику о друштву Србије. Улагање у СОИ има изузетно велики значај за ову популацију, али истовремено представља и значајно улагање у развој и квалитет целог друштва. Искуства других развијених земаља, које су ове чињенице сагледале пре нас, говоре да, у односу на спортске активности, не постоји успешнији, атрактивнији, али ни јефтинијиметод трајне психофизичке рехабилитације особа са инвалидитетом. 3бог свега тога,улагање у СОИпредставља обавезу друштва, алии сјајну приликуда друштво учини нешто веома корисно и добро, како за популацију особа са инвалидитетом, тако и за себе у целини.

\section{ПАРАОЛИМПИЈСКИ ПОКРЕТ И УНАПРЕБЕЊЕ СИСТЕМА СПОРТА РЕПУБЛИКЕ СРБИЈЕ}

Спорт показују веће интересовање за разумевање фактора који воде до искључености, као и до ефикасног менаџмента смањења истих, на шта, на неки начин, упућују и усвојене стратегије спорта у Србији. Акциони план, који проистиче из стратешких докумената, разуме СОИ и даје оквире за смањење искључености, али и гради вредносно-иновативни приступ којим се спорт инструментализује у правцу борбе против свих форми сегрегације у друштву.

Систем спорта чине физичка и правна лица која се баве спортском активношћу, односно делатношћу, као учесници у систему спорта (Ђурђевић, 2015). Систем спорта је сврсисходна целина спорта унутар једне државе која води напретку у појавним областима, какве су спорт, физичко васпитање и спорт за све. Искуство, како оно практично, тако и теоријско, говори да се промене делова или целине система спорта, односа и релација, културе организовања и сл. могу реализовати само кроз консензус свих чинилаца и уз веровање да ће процес промена бити благородан према будућем статусу спорта, спортиста и тренера (Јевтић, 2011).

Криза спортских резултата, који су одувек били један од најбољих начина интеграције различитих чинилаца сваког друштва, натерао је многе умне главе да се позабаве овим питањем, па је на заједничкој седници свих чинилаца спорта Србије, одржане у јулу 2006. године, усвојен Оквир новог система спорта и учињен искорак у креирању окружења за даљи развој спорта у државно независној Републици Србији, a 30.9.2006. усвојен је Устав РС, у којем је и спорт нашао своје место (Јевтић, 2011). Као настојање да се у целости сагледа спорт као моћан инструмент развоја целовитог друштва, иницијативом пре свега националних спортских организација и лобирањем унутар политичких структура Сpбије, законом о Влади и министарствима из 2007. године, формирано је Министарство омладине и спорта. Пре самог политичког реорганизовања у корист спорта, донета је одлука о додељивању националних признања за успехе у спорту. Прва признања су, свечано додељена 15.2.2007. године, и њима је равноправно третиран олимпијски и праолимпијски спорт у Србији. Све ово представљало је сјајан почетакза равноправно и јединствено третирање и уређење система спорта у државно независној Републици Србији. Усвајањем Стратегије развоја спорта у РС, 2.12.2008. године, настављено је са процесом уређења самог спорта и његовог окружења.

За унапређење и развој СОИ у Србији посебно је значајно то што је финансирање врхунског спорта преузела држава. Припрема параолимпијаца за велика такмичења, као и само учешће на истим, јако пуно кошта. Велике расходе СОИ тешко би неко други, осим државе, могао да испрати на дуге стазе. Поред поставке услова за квалитетнију припрему, веома велики значај има и стипендирање најквалитетнијих такмичара, али и национална признања и награде која следују свима онима који остваре врхунске спортске резултате (медаља на ПОИ, светским и континенталним првенствима у параолимпијским спортовима и дисциплинама). Пут до врхунског спортског резултата је веома тежак, како у олимпијским тако и у 
параолимпијским спортовима, а без обезбеђене подршке целог друштва,такви успеси по правилу изостају. Велики успеси наших параолимпијаца у последњих 10 година, поклапају се са временом када су учињене значајне промене у систему спорта Србије. Од укупно 30 спортова, колико је заступљено у Међународном параолимијском комитету, под окриљем Параолимпијског комитета Србије успешно функционише 14 категорисаних параолимпијских спортских грана програма ПОИ: атлетика, стони тенис, стрељаштво, пливање, стреличарство, седећа одбојка, поверлифтинг, бициклизам, скијање, голбал, кошарка у колицима, кану, бадминтон, теквондо. Од накатегорисаних спортских грана свакако највише успеха имали смо у тријатлону и нешто мање џудоу, а такмичења и тренажне активности спроводе се и у боћању, као и плесу у колицима, који јесте члан Међународног параолимпијског комитета мада није на програму ПОИ.

Констатација да је врхунски параолимпијски спорт збринут, навела је одговорне људе који уређују ову област, да акценат интересовања усмере и на остале нивое спорта особа са инвалидитетом. Врхунски спорт је лепа ствар, али је веома мали број оних који се спортом баве на врхунском нивоу. Зато је решење за масовни и рекреативни спорт потражено у јединицама локалне самоуправе. Према Закону о спорту из 2016. (члан 137), јединице локалне самоуправе финансирају средствимабуџета задовољавање потреба и интереса грађана у области спорта, што је веома битно управо за особе са инвалидитетом које желе да се спортом баве, пре свега, ради здравља и личног задовољства. Закон о спорту управо то и препознаје као један од приоритета који се мора поштовати при избору програма који ћесе у текућој години финансирати из буџета јединице локалне самоуправе (члан 138. став 7). Приоритет дефинисан као „Подстицање и стварање услова за унапређење спортске рекреације, односно бављења грађана спортом, посебно деце, омладине, жена и особа са инвалидитетом“ подразумева да се у тој области, пре свих других, обавезно финансирајуодређени програми, у мери која обезбеђује одговарајуће задовољавањепотреба грађана (посебно деце, омладине, жена и особа са инвалидитетом) да се лично бавеспортом. Други програми могу бити одобрени тек након што се задовоље потребе грађанаиз напред наведених приоритетних области. При томе, за разлику од Министарства омладине и спорта, које из буџета може да финансира само програме у гранама спорта које су од посебног значаја за Републику Србију, јединице локалне самоуправемогу, на основу члана 138. став 8. Закона о спорту, да одобравају годишње и посебне програме у свим гранама и областима спорта утврђеним Правилником о спортским гранама и областима спорта у Р. Србији и спортским дисциплинама у оквиру спортских гранаи области спорта (Удовичић, 2016). Поред тога, чланом 4. став 11. Закона о спорту прописано је да ће Р Србија, аутономна покрајина, јединица локалне самоуправе и организације у области спорта нарочито предузимати активности на повећању учешћа деце, младих, жена и особа са инвалидитетому спортским активностима, омасовљавању женских спортских организација и давању равноправног значаја женама и особама са инвалидитетом у спорту. Као приоритет се наводи и изградња и опремање спортских објеката, који морају бити доступни особама са инвалидитетом (Ђурђевић и Ђукић, 2016). Наглашено је да приликом израде просторних и урбанистичких планова, посебно треба водити рачуна о намени простора за спорти рекреацију деце, омладине, лица са посебним потребама и грађана. Дата је препорука да градови средње величине треба да обезбеде функционалне спортске капацитете, док изградњу великих спортских комплекса треба препустити великим градовима. Законом о спорту Републике Србије дефинисано је да све јединице локалне самоуправе, у року од шест месеци од усвајања националне стратегије развоја спорта у Републици Србији, утврђују програме развоја спортана својој територији, у складу са Националном стратегијом (чл. 142 ст. 4). Изузетно, у односу на Стратегијуразвојаспорта у Републици Србији 2014-2018. годинеовај рок је износио годину дана (чл. 192 ст. 5), јер велика већина јединица локалне самоуправе није имала утврђене програме развоја спорта нити искуство у стратешком планирању развоја спорта, па се сматралода је за припрему тог првог програма потребно нешто дуже време. У сваком случају јединице локалне самоуправе су веома озбиљно 
приступиле решавању овог задакта, а спорт особа са инвалидитетом је постао неизоставни део тих програма.

Иако врхунски и професионални спорт нису примарна одговорност јавних власти у локалној самоуправи, то не значи да и ови нивои спорта нису од великог значаја за свако друштво, тако да јавне власти на локалу имају своју улогуи у пружању подршке развоју врхунског и професионалног спорта. Оваква подршка има велики значај који се, пре свега, огледа у повратномутицају врхунског спорта на мотивисање широког круга људи дасе баве спортом, затим економском значају савременог врхунског спорта усвакој заједници и у националној промоцији (па и локалних заједница) кроз постизање врхунских спортских резултата, али и због потребе одређеног кругаљуди (спортиста) да се не задовољавају просечним већ да теже максималнимспортским учинцима. Због свега овога, развој врхунског спорта је, осим директне подршке државе (преко MOC, Параолимпијског комитета Србије и националних спортских савеза), подржан и од стране локалних самоуправа.

\section{СПОРТ ОСОБА СА}

\section{ИНВАЛИДИТЕТОМ У \\ НАЦИОНАЛНИМ СТРАТЕГИЈАМА PAЗВОJА СПОРТА (2009 и 2013)}

Опредељење да се стратегија развоја спорта ради за период од 4 године, створило је могућности да промене не буду сувише инвазивне, као и то да се обезбеди консензус свих чинилаца битних за њену реализацију. Овакав приступ је олакшао и праћење ефеката и корекцију свега што је у реалној примени наишло на проблеме. Сама реализација Стратегије разрађена је и конкретизована кроз Акциони план (МОC РС, 2009), а опоравак и оздрављење спорта у Србији, па и спорта особа са инвалидитетом, поклапа се са доношењем Стратегије развоја спорта РС. Овом приликом посебан осврт дат је на област стратегије која се односи на СОИ.

Као главни циљеви Стратегије развоја спорта у РС 2009-2013 у Области спорта особа са инвалидитетом, назначени су (MOC РC, 2.12.2008):
- унапређење услова за масовније учешће особа са инвалидитетом у спортским активностима и

- подизање друштвене свести о значају и улози спорта особа са инвалидитетом.

За реализацију првог циља, предвиђене су следеће активности:

- утврђивање критеријума за дефинисање позиције врхунског СОИ у односу на позицију осталих видова спортских активности којима се баве особе са инвалидитетом;

- примена програма развоја врхунског параолимпијског спорта и реализовање међународног програма такмичења преко ПОКС;

- примена програма развоја масовног-рекреативног и врхунског непараолимпијског спорта особа са инвалидитетом, као и програма домаћих такмичења преко ССИС;

- примена програма развоја спортских грана: Специјална олимпијада, Спорт глувих и наглувих и Спорт слепих и слабовидих.

Спорт, поред позитивног дејства на психу, физичку способност и независност особа са инвалидитетом, представља и фактор социјалне интеграције и могућност економске и професионалне сатисфакције (Кљајићи сар., 2013). Прихваћена је идеја да се врхунски СОИ финансира преко Параолимпијског комитета Србије, а да се масовни - рекреативни спорт финансира преко Министарства за рад, запошљавање, борачка и социјална питања, Агенције за сарадњу са невладиним сектором, као и јединица локалне самоуправе. На тај начин је раздвојено финансирање програма врхунских спортиста са инвалидитетом и програма који подразумевају спортске сусрете особа са инвалидитетом, као што су манифестације поводом Дана особа са инвалидитетом, Дана жена, Дана државности, разни турнири, сусрети, кампови... Изједначавањем резултата које постижу олимпијци и параолимпијци, омогућено је веома транспарентно категорисање спортиста на основу остварених резултата, али и категорисање појединих спортских грана.На основу резултата, које остварују спортисти са инвалидитетом, могуће је именовати заслужне 
спортисте, спортисте међународног ранга и спортисте савезног ранга, а, по потреби, и спортисте нижих рангова.Може се констатовати да је активност Стратегије „Утврђивања критеријума за дефинисање позиције врхунског спорта особа са инвалидитетом..." успешно планирана и реализована!

Ако се има у виду главна порука параолимпијског покрета, која наглашава да инвалидност не представља препреку у равноправном учешћу у друштву, спорту и постизању циљева (Шиљак, и сар. 2010), сасвим је јасно да стално подизање квалитета услова за тренирање спортиста са инвалидитетом, усавршавање кадрова, као и модернизација опреме и простора, представљају не само основу за остваривање врхунских спортских резултата, већ и пут за унапређивање квалитета живота ове популације. Имајући у виду чињеницу да јетоком три параолимпијска циклуса који су претходили усвајању Стратегије, освојено укупно пет медаља (2008. године у Пекингу две сребрне, у Атини 2004. две бронзане, а у Сиднеју 2000. једна сребрна медаља), а да је након усвајања стратегија развоја спорта за период 2009-2013 и 2014-2018, освојено укупно 14 медаља (у Лондону 5, у Рију 9), може се констатовати да је једна од приоритетних активности Стратегије - развој врхунског параолимпијског спорта, не само реализована, већ је довела до изузетних олимпијских резултата. Генерализујући ове наводе, може се констатовати да је и активност „Примена програма развоја врхунског параолимпијског спорта иреализовање међународног програма такмичењакоја је реализована кроз програмске активности ПОКС“ успешно планирана и реализована.

Стратегијом развоја спорта је, поред примене програма врхунског параолимијског спорта, предвиђена и примена програма развоја масовног-рекративног спорта, као и развој спортских грана Специјална олимпијада, Спорт глувих и наглувих, Спорт слепих и слабовидих, те врхунски непараолимпијски спорт особа са инвалидитетом. Активности које подразумевају развој ових спортских грана су Стратегијом предвиђене као приоритет. Наши спортисти у овим спортским гранама бележе међународне успехе.Национални спортски савез слепих и слабовидих основан је 29.10.2009. године и од свог оснивања бави се шахом, атлетиком, пливањем, голбалом и куглањем, а повремено и другим спортовима (Национални спортски савез слепих и слабовидих, 2018). Сауспесима слепих и слабовидих спортиста упозната је не само спортскавећ и шира јавност. Пуно пута су нас обрадовали копљаши Тања Драгић (двоструки првак света 2011. у Крис Чурџу и у Анталији, првак Европе 2012, злато на ПОИ у Лондону), Немања Димитријевић (бронза на Првенству света 2015, сребрна медаља на Првенству Европе 2016, те бронзе на ПОИ у Рију и Првенству Европе 2018), Милош Грлица, који је бронзаним медаљама са ПОИ у Атини и Првенства света 2007. и титулом првака Европе из 2005. године, након доношења Стратегије „додао“ сребро и бронзу са Првенстава света 2011. у Крис Чурџу и Анталији, те титуле првака Европе 2012. и вицешамиона Европе 2014. године, као и дискаши Стефан Димитријевић и Душко Сретеновић који су на Првенству Европе 2018. освојили бронзане мадаље. Фантастичне успехе остварили су и наши слепи и слабовиди куглаши, а мадаљама са највећих такмичења обрадовали су насшахисти и каратисти (Табела 1). Поред тога, треба истаћи спортисте у голбалу и џудоу, који се не могу похвалити светским медаљама, али су свакако имали запажене наступе на међународној сцени.

Специјална олимпијада Србије почела је са радом2002. годинеи тренутнопокрива 12 спортова (атлетику, пливање, скијање, бадминтон, боћање, куглање, стони тенис, тенис, кошарку, одбојку, рукомет и фудбал).У програму Специјалне олимпијаде је до 2014. године укључено 3000 спортиста, а медаље које су они освојили тешко је и набројати. Све већу популарност и масовност стичу и такмичења мешовитих тимова, које чине спортисти без инвалидитета и особе са интелектуалном ометеношћу. Овакав вид спортских надметања има велики значај за децу са сметњама у развоју, за њихове родитеље, али и за децу без сметњи у развоју, као и за родитеље те деце. Сви они из оваквих активности излазе јачи, бољи и емоционално богатији, а контакти који се на овакав начин успостављају значајно доприносе проналажењу правог места и улоге особа са сметњама у развоју у широј друштвеној заједници. У Србији већ функционише 11 оваквих клубова, а Специјална олимпијада је отворена за све иницијативе укључивања нових спортских грана. 
Спортски савез глувих Србије организује такмичења у чак 16 спортова (атлетика, фудбал, рукомет, кошарка, пливање, рвање, куглање, одбојка, стони тенис, стрељаштво, пикадо, карате, џудо, теквондо и шах). Од 1945. до 2005. године глуви спортисти СФРЈ и СРЈ освојили су 75 медаља (27 златних, 17 сребрних и 31 бронзану) на светским и европским првенствима и олимпијским играма глувих (Спортски савез глувих Србије, 2015), а од 2007. до краја 2018. спортисти овог Савеза су освојили 19 медаља на највећим такмичењима (Табела 1). Тенденција овог Савеза је јасна, да се што већи број спортиста укључи у рад клубова „чујућих“ спортиста. Све оно што је урађено у овим спортским гранама наводи на недвосмислен закључак да је и стратешки циљ „Примена програма развоја спортских грана Специјална олимпијада, Спорт глувих и наглувих и Спорт слепих и слабовидих“ врло успешно планиран и реализован!

Такмичења у непараолимпијским дисциплинама, као што су куглање, оријентиринг, карате, спортски риболов, скијање на води, шах, пикадо, билијар, као и планинарске и алпинистичке туре, имају велику поуларност међу особама са инвалидитетом, а резултати који се у овим спортовима постижу вредни су сваке пажње (Касум, 2015, стр. 157). При томе, број спортских дисциплина није фиксиран, тако да увек остаје отворена могућност да се организују такмичења и у некој новој спортској дисциплини, у којој до сада није било такмичења. Сумирајући ове подухвате може се констатовати да је и активност“Примена програма развоја масовног - рекреативног и врхунског непараолимпијског спорта особа са инвалидитетом, као и програма домаћих такмичења преко ССИС“ успешно спроведена.

Из свега изнетог, може се закључити да је на остваривању првог постављеног циља Стратегије, који је дефинисан као „Унапређење услова за масовније учешће особа са инвалидитетом у спортским активностима“, урађено јако пуно. Створени су солидни услови да се особе са инвалидитетом баве спортом, остварују као врхунски спортисти, као и да се масовност постепено повећава. Наравно, тај процес није готов и на томе се мора стално радити, али је, по овом питању, доста урађено.

За реализацију другог циља Стратегије развоја спорта у РС 2009-2013. у области спорта особа са инвалидитетом, дефинисаног као „Подизање друштвене свести о значају и улози спорта особа са инвалидитетом“, превиђена је активност „Континурана едукација родитеља, представника јединица локалне самоуправе, образовних институција и грађана о значају бављења спортом особа са инвалидитетом и чињеници да су особе са инвалидитетом равноправни учесници спортских такмичења“. Ове активности се константно реализују, тако да је и по овом питању доста тога урађено. Наравно, свест људи се мења спорије од правилника, докумената, закона...., па на томе треба радити стрпљиво и у континуитету. Ипак, неки позитивни ефекти се уочавају. Све већи број родитеља се интересује око тога где њихова деца са инвалидитетом могу да упражњавају спортске активности, али се и активно укључује у спортске активности своје деце. Велики број брошура и атрактивних промотивних материјала намењен је управо родитељима, а родитељи све чешће не само да доводе своју децу на спортске активности, него и учествују у набавци реквизита и припремању полигона, асистирају приликом активности, а често се и лично укључују као активни учесници спортских надметања. Када је реч о стручном кадру, и ту се траже адекватна решења. Примера ради, Спортски савез глувих Србије је констатовао да њихов Савез има свега 7 ангажованих оперативних тренера (два у фудбалу, два у рукомету и три у стрељаштву), те да не могу организовати стручна усавршавања, али зато своје кадрове шаљу на стручно усваршавање које организују грански савези чујућих, а по потреби ангажују спортске стручњаке из савеза чујућих (2015, стр. 4). При факултетима спорта већ десетак година постоје наставни предмети,негде као обавезни, а негде као изборни, који се баве проблематиком спорта особа са инвалидитетом, а остављена је и могућност да студенту ова областбуде усмерење. Поред тога, при факултетима су покренути курсеви за оспособљавање тренера, након којих полазници добијају звање оперативни тренер изабране спортске гране (параолимпијски спортови, непараолимпијски спорт особа са инвалидитетом, Специјална олимпијада, спорт слепих и слабовидих, спорт глувих и наглувих), аинтересовање за ове курсеве је све веће. За само неколико година велики број глуве деце је кроз инклузију укључен у школе са чујућима, 
тако да основне и средње школе глувих имају по 6 до 7\% мање ученика него у периоду до 2011. године (Спортски савез глувих Србије, 2015, стр. 8).На тај начин су ова деца много више упућена на спортске клубове чујућих, а могућности за њихово укључивање у спортске активности су знатно веће. Са друге стране и деца која чују, готово се неосетно навикавају на другаре који не чују, а све ово даје сјајне резултате на подизању укупне друштвене свести.

Укупно гледано, предвиђена активност „Континурана едукација родитеља, представника јединица локалне самоуправе, образовних институција и грађана о значају бављења спортом особа са инвалидитетом и чињеници да су особе са инвалидитетом равноправни учесници спортских такмичења" је доста обухватно планирана и реализована. Истине ради, показатељи спровођења већине ових активности више су приметни у последње 2-3 године, али то не значи да, гледајући временски оквир Стратегије (20092013), она није реализована на време. Едукација је процес који траје, а увек је најтеже осмислити и покренути едукативне акције. Курсеви и семинари који данас имају врло завидан ниво,настали су као логична последица рада у протеклих 6-7 година. Створен је повољан амбијет и анимирана шира јавност.Спровођење ове активност захтева континуитет.

Стратегија развоја спорта у Републици Србији за период 2014-2018. године представља логичан наставак Статегије 2009-2013. године, у којој је посебан акценат стављен на то да се посебне могућности за бављење спортом морају пружити младима, старима и особама са инвалидитетом, односно да своје личности у потпуности развију кроз програме прилагођене њиховим захтевима. На више места је истакнуто да јавне власти свих нивоа у области спорта морају предузети и додатне мере како би особама са инвалидитетом, као и осталим члановима друштва, омогућиле да ефикасно користе могућност бављења спортом, без обзира на то који је степен инвалидности у питању. Тиме је учињен корак у спречавању дискриминације и маргинализације особа са инвалидитетом и повећан обухват бављења спортом ове популације.Као посебни циљеви стратегије назначенисузначајније укључивање јединица локалне самоуправе у финансирање програмских активности из области спорта и спортске рекреације особа са инвалидитетом, као и унапређење сарадње спортске рекреације ca школским и универзитетским спортом, врхунским спортом, спортом у војсци и полицији, радничким спортом и спортом на селу, а све са циљем повећања обухвата бављења спортом особа са инвалидитетом (наравно, и осталих сегмената становништва).

Акционим планом за спровођење Стратегије предвиђено је да сесистемом школског и универзитетског спорта обезбеди социјална интеграција ученика и студената са инвалидитетом. На реализацији ових задатака је рађено, тако да су одржана нека промотивна такмичења по Јунифајд систему, чију основу представља такмичење мешовитих тимова, које чине такмичари са и без инвалидитета. Ова такмичења су веома добра прилика за значајније укључивање ученика и студената са инвалидитетом у спорт (Касум, \& Мијић, 2009), мада до сада још увек није довољно искориштена. Може се закључити да је овај део стратешких циљева у поступку припрема за имплементацију кроз решења којима би се спорт и физичко васпитање вратили на универзитет, како за здраве, тако и за студенте са инвалидитетом.

Обезбеђењеприлазаособамасаинвалидитетом спортским објектима је један од задатака који се успешно реализује. Сви новији спортски објекти имају урађен прилаз за особе са инвалидитетом, док је код велике већине старијих објеката тај прилаз накнадно урађен.

Акционим планом за спровођење Стратегије, постављени су и посебни циљеви који предвиђају да се јединице локалне самоуправе значајније укључе у финансирање програмских активности из области спортске рекреације и СОИ, као и да се унапреди сарадња спортске рекреације особа са инвалидитетом са школским и универзитетским спортом, врхунским спортом, спортом у војсци и полицији, радничким спортом и спортом на селу. Велики број јединица локалне самоуправе је у систем финансирања укључио спортске активности особа са инвалидитетом, тако да су на локалу, у складу са реалним могућностима, често обезбеђени термини, реквизити и спортски стручњаци.Реализација ових активности често се остварује преко организација спорта за све или организација СОИ, па се може констатовати да је задатак „Обезбеђивање институционалног 
капацитета унутар организација спорта за све и СОИ за квалитетно аплицирање програма и пројеката“ реализована.

Поред наведеног, јединице локалне самоуправе имајуобавезудаподстичуиподржавајуодржавање такмичења спортиста са инвалидитетом, а често и стипендирају перспективне спортисте са инвалидитетом. Принципијено је прихваћен став да стипендиста локалне самоуправе не може бити спортиста који добија стипендију Министарства омладине и спорта РC, па је на тај начин обезбеђено да спортисти који још увек нису остварили међународно значајне резултате буду стипендирани од стране јединица локалне самоуправе. Управо на локалу је могуће лакше направити добру процену. Овакав приступ се показао као добар јер стипендисти често, већ после 2-3 године, долазе до значајних успеха и на најпрестижнијим међународним такмичењима.

Већи број корисника рекреативних садржаја даје базу са идентификацију и развој врхунских спортиста са инвалидитетом. Такви садржају су идеална прилка да особа примети да јој нека спортска дисциплина „лежи“, да има смисао и интересовање,као и да потражи пут за задовољење својих интерсовања и жеља. Стратегијом је предвиђено да систем школског и универзитетског спорта обезбеди социјалну интеграцију ученика и студената са инвалидитетом и да обезбеди услове за њихово укључивање у системе спортских такмичења, тако да се може констатовати да је ова активност Стратегије већ сада спроведена.

Стратегијом је предвиђено да се уради анализа стања спортске рекреације и спорта особа са инвалидитетом на нивоу јединица локалне самоуправе, те да се израде препоруке и утврде приоритети за функционисање спорта особа са инвалидитетом у оквиру програма развоја спорта у јединицама локалне самоуправе. Велики број јединица локалне самоуправе је овај задатак врло успешно обавио, о чему сведоче и документа која су доступна на њиховим веб страницама, тако да се и ова мера Акционог плана може сматрати реализованом!

Унапређење стручних потенцијала у спортској рекреацији и спорту особа са инвалидитетом такође је једна од активности које је предвиђена. Едукација и лиценцирањепредстављајуконкретне мере за реализовање ове активности (Митић, 2018). Број лиценцираних тренера у спорту особа са инвалидитетом за сад није велики, али се постено повећава. Наставом на факултетима спорта обухваћена је ова проблематика, одржавају се стручне трибине, семинари и конференције које се баве овом проблематиком, а израђени су и планови стручног оспособљавања и усавршавања, тако да је и ова активност успешно реализована!

\section{ЗАКЉУЧАК}

У савременом свету се квалитет живота и статус, који особе са инвалидитетом имају у друштву, сматрају мером развијености и зрелости тог друштва. Многа искуства у замаља широм света, показала су да спортске активности особа са инвалидитетом представљају најуспешнији, најатрактивнији, али, зашто не рећи и најјефтинији метод њихове трајне психофизичке рехабилитације.

Спорт особа са инвалидитетом у Србији током последње деценије доживљава значајну експанзију и развој, која се огледа кроз остваривање веома значајних спортских резултата на међународној сцени, стварање повољног амбијента за веће укључивање особа са инвалидитетом у спортске активности, али и кроз много прецизније уређен систем организационог повезивања и функционисања клубова и спортских удружења. У Уставу, који је усвојен 2007. године, спорт је нашао своје место, а у систему спорта у Србији позицију потуно равноправну са осталим сегментима спорта, заузео је спорт особа са инвалидитетом.

Стратегијом развоја спорта у Србији, ороченом на период од 2009. до 2013, те од 2014. до 2018. године, јасно су дефинисани циљеви развоја спорта у области спорта особа са инвалидитетом. За реализацију циљева дефинисаних као „Унапређење услова за масовније учешће особа са инвалидитетом у спортским активностима“ и „Подизање друштвене свести о значају и улози спорта особа са инвалидитетом“, предвиђен је и читав низ активности које се спроводе кроз реализацију конкретних задатака и мера.

На основу посматрања индикатора, предвиђених као репер за праћење спровођења Стратегије,могуће је констатовати да се стратегије развоја спорта у Србији у области спорта особа са инвалидитетом добро спроводи. 
Већина предвиђених активности је спроведена, а опредељење да се стратегија развоја спорта ради за период од 4 године, обезбедило је могућност успешног праћења ефеката, као и правовремене корекције свега што у реалној примени наиђе на проблеме.

Све оно што је урађено у претходних десет годиназначајнојеунапредилонивоорганизованости и квалитет параолимпијског и непараолимпијског спорта особа са инвалидитетом у Србији. Резултати остварени на највећим такмичењима су заиста сјајни (Табеле 1 и 2), али у наредном периоду треба уложити значајне напоре да се овај

\section{ЛИТРАТУРА}

1. Bačanac, Lj., Milićević-Marinković, B., Kasum, G. \& Marinković, M. (2014). Competitive Anxiety, Self-Confidence and Psychological Skills in Top Athletes With and Without Disabilities: A Pilot Study. Facta Universitatis, 12(2), 59 - 70.

2. Dausen, V. (1997). Body image of nonclinical and clinical populations of men: A literature revienj. Occup Ther Ment Health, 13, 37-55.

3. Drench, M. E. (1994). Changes in body imagie secondary to disese and injury. Rehabil Nurs, 19, 31-36.

4. Howe, P.D. (2011). Sociology. In Vanlandewijck, C.Y \& Thompson, R.W Ed: The Paralympic Athlete. IOC Publication, Chapter VI, pp 102-116. West Sussex: Weily-Blackwell. https://www.osobesainvaliditetom.rs/attachments/004_Microsoft $\% 20$ Word\%20 \%20UN_Medjunarodna\%20 konvencija $\% 20$ o $\% 20$ pravima $\% 20$ osoba $\% 20$ sa\%20invaliditetom.pdf

5. International Table Teniss Federation: Para Table Teniss: Tournaments (2012-2016). Доступно (11.2.2018.) на http://stats.ipttc.org/tournaments

6. Kasum, G. \& Mijić, Z. (2009). Significance of school sports education in animation and selection of disable athletes. U International Scientific Conference "Theoretical, methodology and methodical aspects of physical education " - Conference proceedings (215-221). Belgrade: Faculty of Sports and Physical Education. покрет додатно популаришеи омасови. Снажан замах, који је по овом питању направљен у минулој декади, потребно је добро искористити у планирању наредних активности.

\section{Напомена:}

Рад је настао у оквиру пројекта „Ефекти примењене физичке активности на локо-моторни, метаболички, психо-социјални и образовни статус српског становништва“, бр. III47015, а део је подпројекта „Ефекти примењене физичке активности на локо-моторни, метаболички, психо-социјални и образовни статус популације особа са инвалидитетом Р. Србије“.

7. Valliant, P. M., Bezzubyk, I. \& Daley, L. (1990). Psychological adaptation to amputation: The role of sociodemographic variables, disability-related, factors and coping strategies. Int J Rehabil Res, 22, 21-31.

8. Winnick, J. R. (1995). Adapted Physical Education And Sport. USA, State University of New York College at Brockport: Human Kinetics.

9. World Taekwondo Europe, Solidarity and Parataekwondo Committee. Results. Dostupno (5.3.2019) na http://worldtaekwondoeurope. com/results

10. Влада Републике Србије (2014). Стратегија развоја спорта у Републици Србији 20142018. Сл. гласник РС, бр. 1/2015.

11. Генерална скупштина УН (2006). Конвенције о правима особа са инвалидитетом. Доступно (13.2.2019.) на

12. Ђурђевић, Н. \& Ђукић, И. (2016). Приручник за финансирање програма у области спорта y јединицама локалне самоуправе. Београд: Стална конференција градова и општинаСавез градова и општина Србије.

13. Ђурђевић, Н. (2015). Приручник за израду програмаразвоја спорта у јединицилокалне самоуправе. Београд: Министарство омладине и спорта Републике Србије.

14. Јевтић,Б. (2011). Рефлексија менаџмента олимпијских програма на систем спорта Србије. СпортЛогиа,7(2),129-140 
15. Касум, Г. \& Младеновић, М. (2017). Самоперцепција спортиста са инвалидитетом. Физичка култура, 71(1), 43-54.

16. Касум, Г. \& Радовић, М. (2007). Анализа потребе за спортом особа са инвалидитетом. У Зборник радова са Међународне научне конферениије "Аналитика и дијагностика физичке активности”"(88 - 97). Београд: Факултет спорта и физичког васпитања и Олимпијски комитет Србије.

17. Касум, Г. (2015). Спорт особа са инвалидитетом. Београд: Факултет спорта и физичког васпитања.

18. Касум, Г., Глигоров, С. \& НастасићСтошковић, Т. (2011). Борилачки спортови за особе са инвалидитетом. Физичка култура, 65(1), 60-69.

19. Кљајић. Д., Допсај, М., Еминовић, Ф. \& Касум, Г. (2013). Спорт у рехабилитацији особа са инвалидитетом. Здравствена заштита, 42(3), 58-66.

20. Министарство омладине и спорта Републике Србије (2008). Стратегија развоја спорта у Републици Србији 2009-2013. Службени гласник РС, бр. 110/2008.

21. Министарство омладине и спорта Републике Србије (2009). Акциони план за спровођење Стратегија развоја спорта у Републици Србији 2009-2013. године. Београд.

22. Министарство омладине и спорта Републике Србије (2013.). Правилник о националној категоризацији спортова. Службени гласник РС», бр. 25/2013. Београд:.

23. Министарство омладине и спорта Републике Србије (2016.). Правилник о спортским гранама и областима спорта у Републици Србији и спортским дисциплинама у оквиру спортских грана и области спорта. Службени гласник РС, бр 51/16. Београд

24. Министарство омладине и спорта Републике Србије (2016.). Правилник о спортским гранама од посебног значаја за Републику Србију. Службени гласник РС, бр 95/16.
25. Митић, Д. (2018). Прилогза годишњи извештај о спровођењу Стратегије развоја спорта y Републици Србији за 2017. годину. Београд: Документ, Факултет спорта и физичког васпитања.

26. Мићовић, 3. (2014). Параолимпијски комитет Србије. Доступно (30.9.2017) на http://www. paralympic.rs/organizacija/predsednik

27. Народна скупштина Републике Србије (2016.). Закон о спорту. Службени гласник бр. 10/16.

28. Национални спортски савез слепих и слабовидих (2018). O нама. Доступно (4.2.2018) на http://nssss.co.rs/o-nama.php

29. Орлић, А., Пејчић, Б., Лазаревић, Д. \& Милановић, И. (2016). Предиктори става студената према инклузији деце са развојним сметњама у наставу физичког васпитања. Физичка култура, 70(2),126-134.

30. Покрајински секретаријат за спорт и омладину (2008). Спорт особа са инвлидитетом. Стратегија развоја спорта у АП Војводини (103-112). Нови Сад. Доступно (11.9.2017.) на http://njnjnj.sio.vojvodina.gov.rs/indedž. $\mathrm{php} / \mathrm{sport} /$ sport-za-sve/8-sport/225-strategijarazvoja-sporta-u-ap-vojvodini

31. Спорски савез Србије (2017). Публикације. Доступно (4.2.2018.) http://www.serbiansport. com/publikacije

32. Спортски савез глувих Србије (2015). Стратегија развоја Спорта глувих у периоду 2015-18.2. Доступно на: http://njnjnj.ssgs.rs/ Strategija\%20razvoja\%20sporta\%20gluvih\% 20u \% 20periodu \%202015\%20\%202018.\%20 godine.pdf

33. Уредба о националним признањима и наградама за посебан допринос развоју и афирмацији спорта. Службени глас. РС бр. $65 / 06,6 / 07,24 / 09$ и 88/09.

34. Шиљак, В., Стефановић, Ђ., Плакона, Е., Касум, Г. \& Авдибашић-Вукадиновић, Н. (2010). Феномен Летњих параолимпијских игара. Физичка култура, 64(2), 68-75. 